\title{
RESPONSE OF TWO NEWLY DEVELOPED CORN GENOTYPE (Zea mays, L) TO SOME TRACE ELEMENTS UNDER SALT STRESS THROUGHOUT THEIR GROWTH LIFE SPANE: 1- MORPHOLOGICAL AND GROWTH CHARACTERS Helaly, M. N. ; A. A. Arafa ; R. A. Fouda and H. F. Esmail Dept. of Agric. Botany, Fac. of Agric., Mansoura Univ.
}

\begin{abstract}
Two pot experiments were carried out at the greenhouse and laboratories of the Agricultural Botany Department, Faculty of Agriculture, Mansoura University, Egypt during the two seasons of 2002 and 2003 to study to what extent the experimented treatments of some trace-elements applied either as a spray or as a soil feeding may improve salt tolerance and reduce of salt induced necrosis in maize plants; Zea mays, L. Two newly cultivars were chosen; Bachaier 13 single cross and TWC 310 denoted cultivar (1) and cultivar (2), respectively.

Four levels of artificial saline sea water having E.C. values of $0.36,2.5,5$ and $7.5 \mathrm{dsm}^{-1}$ were used and denoted control, low, high and highest level respectively. $\mathrm{Zn}$, $\mathrm{Fe}$ and /or Mn trace-elements were investigated. The experiments were laid out as a factorial complete randomized block design system with 8 replication, four of them were used for the morphological as well as growth characters and analyzed statistically.

The general observation was the higher values of growth parameters in cultivar (1) than those obtained with cultivar (2) throughout the experimental period during the two growing seasons.

The plants in the two cultivars were growing slowly under salinity and were dwarfing, stunting, inferior in size and unhealthy in general appearance. The effect of salinity was more pronounced in cultivar (2) than cultivar (1). Plants were shorter, thin and the rate of leaf production and leaf size were much reduced. Plants showed obvious changes in colour if compared to the control plants. As the salinity level increased the stunting was more noticeable; the leaves of the two cultivars become dull coloured, often bluish-green, and frequently coated with a waxy deposit. Plants of cultivar (2) failed to grow up to the $2^{\text {nd }}$ sample; tassiling stage, under salinity even at $2.5 \mathrm{dsm}^{-1}$.

With respect to the power of survival which is taken as a criterion of salt tolerance, it was found that cultivar (2) plants could not tolerate any level of salinity even at $2.5 \mathrm{dsm}^{-1}$, while cultivar (1) plants tolerate salinity up to $5 \mathrm{dsm}^{-1}$ and died only at the level of $7.5 \mathrm{dsm}^{-1}$.

Salinized plants started to bloom earlier than did in the control in cultivar (1). Such effect was increased with an increase in salinity level and amounting to 5-7 days at the $7.5 \mathrm{dsm}^{-1}$. The effects of trace-elements indicated that $\mathrm{Zn}, \mathrm{Fe}$ and/or $\mathrm{Mn}$, especially $\mathrm{Zn}$ treatments, improved growth of the two cultivars during the two growing seasons. The proven efficiency of these elements was more pronounced in cultivar (1) plants than did in cultivar (2) and depending on the salinity levels.

The interactions treatments indicated that, micronutrients treatments counteracted the harmful effect of salinity on cultivar (1) plants compared with the corresponding control. Therefore, the treated plants tolerate salinity up to the highest level of salinity; $7.5 \mathrm{dsm}^{-1}$. In cultivar (2) plants, $\mathrm{Zn}$ treatments only improved their tolerance but up to the high level; $5 \mathrm{dsm}^{-1}$ only whereas other nutrients failed to
\end{abstract}


Helaly, M. N. et al.

improve the plants to grow under the salt stresses used, since the salinized plants died before tasseling stage.

Keywords: Corn, maize, salinity, trace-elements.

\section{INTRODUCTION}

Corn , maize (Zea mays, L.), Poaceae is one of the most important cereal crops grown in Egypt. It occupies a large scale area of irrigated soils ca. 165800 feddan producing about 5756000 tons every year (Agric. Rec. Cent., ARC Ministry of Agricultural, Egypt, 2003) . Certain efforts should be done to overcome the serious gap between maize production and its demand to consume in human and animal nutrition .

The productivity of corn is limited by the genotypes and influenced by the abiotic factors especially water supply and soil salinity. Salinity is one of the acute problems affecting soil in the arid and semi-arid regions including Egypt (Nuttal et al., 2003). Plants grown in salt stress usually suffer from several nutritional disturbances particularly those concerning micro-nutrients. These factors together focused the attention on plant species and cultivars better adapted to such condition. It was found that fertilization minimize the hazardous effects of salinity on plant growth. Marschner, (1995) suggested that increasing fertilization may alleviate some of the inhibitory effects of salinity. The interactions between soil fertility, salinity and cultivated crops are of major interest in optimizing crop growth under salinity (Magelhaesa, et al., 2000).

Therefore, the present investigation aimed to study the possible effects of using easily applicable inexpensive treatments of some micronutrients. on growth of both root and shoot systems of two newly developed corn cultivars grown under saline conditions hoping to improve their tolerance capacity.

\section{MATERIALS AND METHODS}

Pot experiments were designed in the greenhouse and of the Agricultural Botany Department, Faculty of Agriculture, Mansoura University, Egypt during the two growing seasons of 2002and 2003.

The mechanical and chemical analyses of the soil used was carried out in the two growing seasons as described by Jackson (1973) and Page et al (1982) and presented in Table (1).

Four levels of artificial sea water were used by dissolving known weight of natural salt crust, in tape water. The natural salt crust was brought directly from the salterns of Rashid, El-Beheira Governorate, Egypt. The four salinity levels: Tap water $\left(0.36 \mathrm{dsm}^{-1}\right), 2.5,5$ and $7.5 \mathrm{dsm}^{-1}$ denoted as control, low, high and highest levels, respectively. To obtain 4 levels of soil salinity, EC of the pots media was measured in soil past extract (SPE) and soluble salts percentages (SSP) were calculated from the equation of Richard's (1954) as follows:

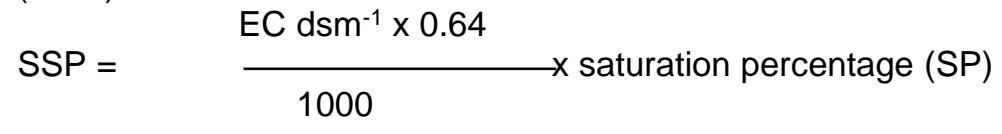


Table (1):The physiochemical properties of the soil used during the two growing seasons of 2002 and 2003.

\begin{tabular}{|c|c|c|c|c|c|c|c|c|c|c|c|}
\hline \multirow[b]{3}{*}{ Season } & \multicolumn{11}{|c|}{ 1. Mechanical analysis } \\
\hline & \multicolumn{10}{|c|}{ Soil fraction \% } & \multirow{2}{*}{$\begin{array}{l}\text { pH soil } \\
\text { paste }\end{array}$} \\
\hline & \multicolumn{2}{|c|}{ Sand coarse+fine } & \multicolumn{2}{|c|}{ Silt } & Clay & \multicolumn{3}{|c|}{ Organic matter } & \multicolumn{2}{|r|}{$\mathrm{CaCO}_{3}$} & \\
\hline 2002 & \multicolumn{2}{|c|}{86.02} & 6.30 & \multicolumn{2}{|r|}{6.18} & \multicolumn{3}{|c|}{0.32} & \multicolumn{2}{|r|}{1.18} & 7.8 \\
\hline \multirow[t]{4}{*}{2003} & \multicolumn{2}{|c|}{86.20} & 6.4 & \multicolumn{2}{|r|}{6.09} & \multicolumn{3}{|c|}{0.29} & \multicolumn{2}{|r|}{1.02} & 7.9 \\
\hline & \multirow{2}{*}{\multicolumn{6}{|c|}{$\begin{array}{c}\text { 2. Chemical ana } \\
\text { CATION (meq/l) }\end{array}$}} & nalysi & & & & \\
\hline & & & & & & & \multicolumn{5}{|c|}{ ANION (meq/l) } \\
\hline & & $\mathbf{C a}^{++}$ & $\mathrm{Mg}^{++}$ & $\mathrm{Ne}$ & & $\mathrm{K}^{+}$ & & $\mathrm{CO}_{3}{ }^{-}$ & $\mathrm{CO}_{3}^{--}$ & $\mathrm{SO}_{4}^{--}$ & $\mathrm{Cl}^{-}$ \\
\hline 2002 & 0.36 & 0.86 & 0.61 & 0.4 & 48 & 0.19 & & 20 & -- & 0.34 & 0.60 \\
\hline \multirow[t]{4}{*}{2003} & 0.32 & 0.82 & 0.65 & & 53 & 0.14 & & .17 & -- & 0.30 & 0.67 \\
\hline & \multicolumn{11}{|c|}{ 3. Nutrients analysis } \\
\hline & \multicolumn{7}{|c|}{ Macronutrients (mg/100 g soil) } & \multicolumn{4}{|c|}{ Micronutrients (ppm) } \\
\hline & $\mathbf{N}$ & $\mathbf{P}$ & K & $\mathbf{C a}$ & Mg & & $\mathrm{Na}$ & Fe & Mn & Zn & $\mathrm{Cu}$ \\
\hline 2002 & 7.62 & 0.62 & 6.50 & 24.00 & 22.1 & & 30.2 & 2.79 & 3.10 & 0.62 & 0.41 \\
\hline 2003 & 8.00 & 0.50 & 6.44 & 25.10 & 21.7 & & 32.5 & 3.10 & 3.02 & 0.54 & 0.50 \\
\hline
\end{tabular}

The amount of salt for each salinity level was calculated, dissolved in the proper amount of tap water and used for irrigation.

Chemical analyses of the natural salt crust used for salinization were determined according to the standard procedures described by Piper (1950) and Jackson (1973) and the composition of the four salt solutions are presented in Table (2).

Table (2): Chemical composition analyses of the natural salt crust used for salinization (meq/100g) and the four salinity levels used (meq/l).

1. Chemical composition analyses of the natural salt crust used for salinization process

\begin{tabular}{|c|c|c|c|c|c|c|c|c|c|c|}
\hline \multicolumn{5}{|c|}{ CATION (meq/l) } & \multicolumn{6}{|c|}{ ANION (meq/l) } \\
\hline $\mathrm{Ca}^{++}$ & $\mathrm{Mg}^{++}$ & $\mathrm{Na}^{+}$ & \multicolumn{2}{|c|}{$\mathrm{K}^{+}$} & $\mathrm{HCO}_{3}^{-}$ & \multicolumn{2}{|c|}{$\mathrm{CO}_{3}{ }^{--}$} & $\mathrm{SO}_{4}^{--}$ & \multicolumn{2}{|c|}{$\mathrm{Cl}^{-}$} \\
\hline 40.92 & 54.11 & 1500.0 & \multicolumn{2}{|c|}{4.98} & 10.94 & --- & \multicolumn{2}{|c|}{148.35} & \multicolumn{2}{|c|}{1440.72} \\
\hline \multicolumn{11}{|c|}{ 2. Chemical composition analyses of the four salinity levels used } \\
\hline \multirow{2}{*}{\multicolumn{3}{|c|}{\begin{tabular}{|l|l|} 
Salinity levels used & $\begin{array}{l}\text { E.C } \\
\text { dsm }^{-1}\end{array}$ \\
\cline { 1 - 2 }
\end{tabular}}} & \multicolumn{4}{|c|}{ Caons (meq/l) } & \multicolumn{4}{|c|}{ Anions (meq/l) } \\
\hline & & & $\mathrm{Ca}^{++}$ & $\mathrm{Mg}^{++}$ & $\mathrm{Na}^{+}$ & $\mathrm{K}^{+}$ & $\mathrm{HCO}_{3}^{-}$ & $\mathrm{CO}_{3}$ & $\mathrm{SO}_{4}=$ & $\mathrm{Cl}^{-}$ \\
\hline Control & & 0.36 & 0.34 & 0.35 & 1.21 & 0.14 & 0.57 & -- & 0.22 & 1.25 \\
\hline Low & & 2.5 & 0.50 & 0.75 & 26.2 & 0.16 & 0.80 & -- & 14.0 & 12.8 \\
\hline High & & 5.0 & 0.75 & 1.24 & 50.63 & 0.18 & 1.28 & -- & 26.49 & 25.02 \\
\hline Highest & & 7.5 & 0.91 & 1.70 & 76.25 & 0.21 & 1.28 & -- & 40.01 & 37.78 \\
\hline
\end{tabular}

3. Salt composition ( $\mathrm{g} / 100 \mathrm{~g}$ salt) of the salt crust used in irrigation water salinization

\begin{tabular}{|c|c|c|c|c|c|}
\hline $\mathrm{Ca}\left(\mathrm{HCO}_{3}\right)_{2}$ & $\mathrm{CaSO}_{4}$ & $\mathrm{~K}_{2} \mathrm{SO}_{4}$ & $\mathrm{MgSO}_{4}$ & $\mathrm{Na}_{2} \mathrm{SO}_{4}$ & $\mathrm{NaCl}$ \\
\hline 0.888 & 2.040 & 0.425 & 3.247 & 4.216 & 83.07 \\
\hline
\end{tabular}

Each treatment was replicated 8 times. Thus, a total of 984 pots were prepared by code numbers. Four replicates of them were kept till the end of the experimental period and used for the morphological and growth characters. The pots were arranged in a factorial complete randomized block design system.

Before sowing, each pot in the two growing seasons was fertilized with $2 \mathrm{~g}$ calcium superphosphate; $15 \% \mathrm{P}_{2} \mathrm{O}_{5}(200 \mathrm{~kg} / \mathrm{fed})$. Potassium sulphate; $48 \% \mathrm{~K}_{2} \mathrm{O}$ and Ammonium nitrate; $33.5 \% \mathrm{~N}$ were used for 
Helaly, M. N. et al.

potassium and nitrogen fertilization at the rate of 100 and $150 \mathrm{~kg} / \mathrm{fed}$, respectively i.e. $1.4 \mathrm{~g}$ from the former and $5.0 \mathrm{~g}$ from the later per pot in two equal portions. The first portion was added 20 days after sowing and the second at 30 days later. So, the recommended fertilization dose was $130 \mathrm{~N}+$ $48 \mathrm{~K}_{2} \mathrm{O}+30.0 \mathrm{P}_{2} \mathrm{O}_{5}$ unit/feddan according to the Agriculture Research Center; ARC, Ministry of Agric., Egypt. The obtained corn grains were sterilized by dipping successively into mercuric chloride $(0.001 \%)$ and aqueous ethanol $(70 \%)$ for two minutes each, then washed with tap water and planted. Five grains were sowed in the $1^{\text {st }}$ June in the two growing seasons of 2002 and 2003 by distributing them uniformly in the soil at a depth of $1 \mathrm{~cm}$. The pots were watered immediately with the specific irrigation saline water treatments after sowing, and thinned to 3 plants per pot at the $17^{\text {th }}$ day from sowing; $5^{\text {th }}$ leaf stage of growth. Irrigation with the appropriate saline specific water was carried out whenever required. Other usual cultural practices of maize cultivation were carried out according to those recommended by the Ministry of Agriculture, Egypt.

Enough amounts of the specific irrigation water were added to bring the moisture content well over saturation capacity which had previously determined.The accumulation of salts on the media were leached out once every two irrigations using enough amount of the specific saline water calculated according to the following equation (Richard's, 1954).

Leaching Requirements (L.R.) $=D_{\mathrm{dw}} / \mathrm{D}_{\mathrm{iw}}=\mathrm{EC}_{\mathrm{iw}} / \quad \mathrm{EC}_{\mathrm{dw}}$

Where: $D_{d w}$ and $D_{\text {iw }}$ represent the equivalent depth of drainage and depth of irrigation water

$E C_{i w}$ and $E_{d w}$ represent the electric conductivity of the irrigation and drainage water, respectively.

The pots in each saline level were thoroughly leached with sufficient amounts of the desired saline solution to salinize the growth media with the specific examined level as well as to reach the soil at saturation and to yield the required level of salinity. The salinization process was done at a month before corn grains sowing in both seasons to reach the soil at equilibrium. The following different treatments were chosen as easily applicable inexpensive treatments which would improve the salt tolerance capacity of the two cultivars under the previous four salinity levels.

1- Control plants: Plants were treated twice with distilled water during the early vegetative growth period; the $1^{\text {st }}$ after 20 and the $2^{\text {nd }}$ at 30 days from sowing.

2- Plants were sprayed twice with either of $\mathrm{Zn}, \mathrm{Mn}$ and /or $\mathrm{Fe}$ at the recommended rates as obtained from the promising treatments of the preliminary experiments. Spraying took place twice till dripping during the vegetative growth period; after 20 and 30 days from sowing. The traceelements chosen at the recommended doses were used alone or in combinations and supplemented with $0.025 \%$ Tween 20 solution as a wetting agent.

3- Plants were fertilized by soil feeding with the former trace-elements used at the same doses in two equal portions at 20 and 30 days after sowing supplemented with the specific salinized-irrigation water. 
Micronutrients; Foliafeed zinc $15 \%$ chelated (EDTA), Foliafeed chelated manganes 15\% and Folifeed chelated iron 13\% registration numbers 1890, 1891 and 1892, respectively by the Ministry of Agriculture, Egypt were used. Foliafeed micronutrients produced by Advanced Agrochemicals Co., New Nubariya City, Egypt. The recommended rate by the preliminary experiments of the present investigation $(250 \mathrm{~g}$ from each powder /feddan) were used.

The experiments were laid out as a factorial complete randomized block design system.

\section{Sampling dates and data recorded:}

plant samples were taken from each treatment of the two cultivars used if possible for growth parameters at 35,65 and 115 days from sowing coincided as best as possible with the following physiological stages: 10 leaved plants, tasseling and harvesting.

At each sampling date, the chosen plants were cut off at the soil surface, and divided into their leaves including sheathes as well as stems and reproductive organs if present. The roots systems were carefully removed from the pots and cleaned from the surrounding soil particles by suspending the root system in running water to ensure minimum loss of the fine rootlets from the root system. For the growth parameters determinations, plant height, stem diameter, leaf area per plant calculated as recorded below as well as fresh and dry weights of the root system, leaves and stems with reproductive organs if present were recorded. Days from sowing till the beginning of tasseling was also calculated. Leaf area ( $\mathrm{cm}^{2} /$ plant) was determined using disk method ( Johanson, 1967). Samples of ten disks $\left(7.85 \mathrm{~cm}^{2}\right)$ were taken from the third fresh leaf from plant tip and oven dried to calculate the average dry weight relationships. Leaf area per plant was calculated in square centimeters $\left(\mathrm{cm}^{2}\right)$ using the following formula:

Leaf area /plant $\left(\mathrm{cm}^{2} /\right.$ plant $)=$ Leaf dry weight $(\mathrm{g}) \times$ disk area $\left(\mathrm{cm}^{2}\right) /$ Disk dry weight $(\mathrm{g})$

The following parameters were also estimated according to the formula outlined by Radford (1967) as follows:

Specific leaf area (SLA) $\left(\mathrm{dm}^{2} / \mathrm{g}\right)=$ Leaf area /plant $\left(\mathrm{dm}^{2}\right) /$ Leaf weight/plant $(\mathrm{g})$ Leaf area ratio $(\mathrm{LAR})\left(\mathrm{cm}^{2} / \mathrm{g}\right)=$ Leaf area $/$ plant $\left(\mathrm{cm}^{2}\right) /$ Total dry weight/plant $(\mathrm{g})$ Specific leaf weight $(\mathrm{SLW})\left(\mathrm{g} / \mathrm{dm}^{2}\right)=$ Leaf dry weight /plant(g)/Leaf area/plant $\left(\mathrm{dm}^{2}\right)$ Leaf weight ratio $(\mathrm{LWR})=$ Leaf dry weight /plan $(\mathrm{g}) /$ Total dry weight/plant $(\mathrm{g})$

The remained plant material was subsequently oven dried at $70{ }^{\circ} \mathrm{C}$ for 48 hours in an electric oven to a constant weight and their crud dried weights were measured and the moisture percentages (leaf water potential; LWP) was calculated according to the formula of Peynado and Young (1968) as follows:

$$
\text { Fresh weight - dry weight (g) }
$$

$$
\text { LWP }=\quad \times 100
$$

Fresh weight $(\mathrm{g})$

Determination of leaf relative turgidity (LRT) was also carried out as presented by Eisa (1998) as follows: Ten discs were picked up from the $3^{\text {rd }}$ 
Helaly, M. N. et al.

leaf from the plant tip, each one of them has one $\mathrm{cm}$ in diameter and the following formula was used:

Fresh weight - dry weight

$$
\text { LRT }=\frac{}{\text { Turgid weight }- \text { dry weight }} \times 100
$$

The analysis of variance was done in the present investigation as regular two way classification out-lined by Gomez and Gomez (1984). F-test was used for significance. Salinity, treatments and their interactions were tested against the error variance (salinity $x$ treatments). If the $F$ value foe entries is found to be significant the LSD (Least Significant Difference) at 5\% of probability was considered a valid least for the above planned comparisons of means.

\section{RESULTS AND DISCUSSION}

\section{Observation during growth:}

Continuous morphological observations were recorded throughout the experimental period of the plant growth of corn cultivars during the two growing seasons. The general observation was the higher values of growth parameters in cultivar (1) than those obtained with cultivar (2) throughout the experimental period during the two growing seasons. The plants in the two cultivars were growing slowly under salinity and were dwarfing, stunting, inferior in size and unhealthy in general appearance. The effect of salinity was more pronounced in cultivar (2) than cultivar (1) throughout the experimental period during the two growing seasons. Plants were shorter, thin and the rate of leaf production and leaf size were much reduced. Increasing osmotic pressure of the soil solution in the sodic saline media decreased water absorption by the root system and this may extract its effects on the elongation of cells during their growth. Plants showed obvious changes in colour if compared to the control plants. As the salinity level increased the stunting was more noticeable; the leaves of the two cultivars plant become dull coloured, often bluish-green, and frequently coated with a waxy deposit. Plants of cultivar (2) failed to grow up to the $2^{\text {nd }}$ sample; tassiling stage, in salinity level above $2.5 \mathrm{dsm}^{-1}$. Such symptoms may be attributed to disturbances in various metabolic processes (Richard's, 1954 and Hanafy Ahmed, 2002).

The greatest deleterious effects of salinity was produced by chloride addition, mainly when chloride was combined with calcium and/or sodium. Ch'yung Van-Lung and Lapine (1975) found that plant productivity and photosynthetic activity in the plant tissues were recorded more by $\mathrm{NaCl}$ than by $\mathrm{Na}_{2} \mathrm{SO}_{4}$. In the work of Gupta and Nauriyal (1975) it was found that $0.1 \%$ chloride was more injurious than $0.34 \%$ sulphate or $0.09 \%$ carbonate. Carbonate and bicarbonate salts were more detrimental than sulphate and chloride and the latter was more toxic than sulphate. This was strengthened by the recognization of the salt crust composition used for irrigation water salinization in the present investigation as shown in Table (3). 
With respect to the power of survival which is taken as a criterion of salt tolerance (Richard's, 1954), it was found that cultivar (2) plants could not tolerate any level of salinity even at $2.5 \mathrm{dsm}^{-1}$, while cultivar (1) plants tolerate salinity up to $5 \mathrm{dsm}^{-1}$ and died only at the level of $7.5 \mathrm{dsm}^{-1}$. Moreover, salinized plants started to bloom earlier than did in the control in cultivar (1). Such effect was increased with an increase in salinity level and amounting to 5-7 days at the $7.5 \mathrm{dsm}^{-1}$. The provide elapsed four the $1^{\text {st }}$ sample to the second; tassiling in cultivar (1) varied widely as compared to those of cultivar (2).

Regarding the effects of trace-elements, it was found that $\mathrm{Zn}, \mathrm{Fe}$ and/or Mn, especially $\mathrm{Zn}$ treatments, improved growth of the two cultivars during the two growing seasons. The proven efficiency of these elements was more pronounced in cultivar (1) plants than did in cultivar (2) and depending on the salinity levels. In saline condition, micronutrients treatments counteracted the harmful effect of salinity on cultivar (1) plants compared with the corresponding control. Therefore, the treated plants tolerate salinity up to the highest level of salinity; $7.5 \mathrm{dsm}^{-1}$. In cultivar (2) plants, $\mathrm{Zn}$ treatments only improved their tolerance but up to the high level; $5 \mathrm{dsm}^{-1}$ whereas other nutrients failed to improve the plants to grow under the salt stresses used. However, all micronutrients treatments could not improve salt stress of cultivar (2) plants toward the end of experiment, since it died before tasseling stage. Moreover, it was found that the efficiency of micro-nutrients on improving salt tolerance was decreased with an increase in salinity level. The sensitivity of cultivar (2) plants to salt stress compared with the well ability of cultivar (1) to tolerate more salinity level may be due to the genitical variances between the two cultivars used and its influence on the internal composition balances required for normal growth and physiological processes.

Regarding the method of trace-elements application, it was found that foliar application with micronutrients acquires considerable significance compared with that of soil feeding on improving growth of the two corn cultivars examined as an important means of influencing productivity during the two growing seasons, overall salinity levels and/or trace-elements treatments. Spraying should be maximize out pot, by achieving the best possible yield with lower possible losses throughout leaching, fixing, immobilization ... etc. Therefore, plants fertilized with the recommended NPK + trace -elements, as a praying method, showed a general good appearance especially with that of cultivar (1) grown under the non salinized condition.

The (S) or sigmoid growth curve was found in the two cultivars studied throughout their growth cycle overall salinity levels and/or traceelements treatments during the two growing seasons. The high growth rate was recorded between the $1^{\text {st }}$ and the $2^{\text {nd }}$ sampling date, i.e. the tasseling stage. The rapid growth rate of maize in the early stages is responsible for its need for a liberal dressing of readily available nutrients.

Root length and number of adventitious roots:

It is clear from Table 3 that root length and number of adventitious roots under different treatments were similar in the two cultivars studied 
Helaly, M. N. et al.

during the two growing seasons, since it gradually increased from the vegetative growth stage till maturity.

In both cultivars, salinity caused a significant decrease in root length at all growth stages of plant growth during the two growing seasons in comparison to the un-salinized plants. Moreover, it conspicuous that, plants under the highest level of salinity; $7.5 \mathrm{dsm}^{-1}$ recorded the lowest values and the reduction continued till maturity. Similarly plants grown under the highest salinity level showed a significant decline in the number of adventitious roots at tassiling and maturity stages compared with the normally supplied control plants. However, under low and high salinity levels; $\left(2.5\right.$ and $\left.5 \mathrm{dsm}^{-1}\right)$ the decrease was insignificant throughout the experimental period during the two growing seasons. The harmful effects of salinity noticed on root length as well as number of adventitious roots may be due to the suppressing effects of salinity on both meristimatic cell division and elongation as well as root penetration (Hatung, 2004). The situation with respect to the effects of salinity on number of adventitious roots seems to be linked with the genetical composition (Esmail, 1999) of the genotype used and the effects of salinity are limited in this respect. Eisa (1998) reported that water stress substantially induces loss of turger which affects the rate of cell expansion and ultimate cell size.

Regarding the effects of trace-elements on root length and number of adventitious roots, it was found that trace-elements, overall salinity levels, increased root length whereas number of adventitious roots was not affected significantly.

The interaction treatments showed that trace-elements counteracted the inhibiting effect of salinity on root elongation in both cultivars with the superiority of $\mathrm{Zn}$ treatments in this respect. Number of adventitious roots was not affected significantly.

\section{Plant height:}

As it is shown in Table 3 plant height of the two cultivars, showed a continuous increase in plant height with age till the last sampling date. The highest rate of such increase was detected between the $1^{\text {st }}$ and $2^{\text {nd }}$ sampling dates indicating a rapid elongation of the main stem during this period.

Regarding the effect of salinity, a significant decrease in plant height of both cultivars was noticed with increasing salinity level throughout the experimental period during the two growing seasons. Plant height of cultivar (2) seem to have been more affected by salinity than cultivar (1). The dwarfing effects of salinity on plant height was previously reported by several investigators (Haggag, 2001 on corn and Hanafy Ahmed et al, 2002 on some sorghum cultivars). They reported that salinity suppressed both meristimatic cell division and elongation.

The obtained results showed in the same table indicated that plant height of the two cultivars of corn were much increased in plants sprayed with all trace elements used than did the plants received theses elements by soil feeding throughout the experimental period during the two growing Concerning the effects of trace elements, data in the same table show that almost all of the various treatment had significant effects on plant height of the two corn cultivars grown overall salinity levels and throughout the 
experimental period during the two growing seasons. The high values were detected with plants sprayed with $\mathrm{Zn}$ alone or in combinations with other trace-elements used. However, less increase was recorded in Fe-sprayed plants. The beneficial effects of trace-elements on plant height and their effects on restoring salt stress may be attributed to the effects of these elements on increasing growth vigour, photosynthetic product accumulation, meristematic activity of the plant tissues and increasing the cell elongation as well (Hatung, 2004).

Number of days from sowing to the beginning of tasseling:

Data in Table 3 indicate that the number of days from sowing to the beginning of tasseling was considerably affected by the maize cultivar used. Cultivar (2) was bloomed earlier than cultivar (1) by about 5-7 days in the first and second seasons, respectively overall salinity levels and micronutrients treatments. Therefore cultivar (2) showed shorter growing period and earlier maturation than cultivar (1). This may be due to the differences in genetical composition of the tested cultivars (Esmail, 1999) and their different ability to tolerance the environmental condition.

seasons. Moreover, It can be stated that plant height values in cultivar (1) were generally highest than those of cultivar (2), but their response towards increasing salinity was almost similar.

On the other hand, it was found that plants of the cultivar (2) could not tolerat high salinity level more than $2.5 \mathrm{dsm}^{-1}$ and died before reached the $3^{\text {rd }}$ sampling date; so that they were available only for the first two samples. However, plants of the cultivar (1) tolerated salinity and abled to grow in salinity at $5 \mathrm{dsm}^{-1}$ till the last sampling date and at $7.5 \mathrm{dsm}^{-1}$ but died before tasseling.

Salinity, overall micronutrients treatments, decreased the period from sowing to tasseling especially in cultivar (2). Helaly (1972) mentioned that the checking of vegetative growth due to salinity may hasten maturation and final harvest dates especially of crops having indeterminate growth habits such as potato, cotton, melon, ...etc.

The hasten effects of trace elements may be due to the role of these elements in encouraging the meristimic activity to create a strong and healthy plants, which intern puch maize plants towards building the sexual organs early (Hatung, 2004).

Specific leaf area (SLA) and leaf area ratio (LAR):

As presented in Table (4), the trends of specific leaf area and leaf area ratio as affected by salinity, trace-elements and their interactions treatments were similar in the two cultivars examined during both growth seasons, since the values were high at the vegetative growth stage than decreased gradually till maturity. In addition, the data show that salinized plants recorded significant decreases in specific leaf area and significant increases in leaf area ratio at all sampling dates throughout the experimental period during the two growing seasons in both cultivars studied. Similar results were reported by Eisa (1998) on sesame plants grown under water deficit. However, the values recorded in cultivar (1) was found to be lower than that found in cultivar (2). 
Helaly, M. N. et al.

3 
J. Agric. Sci. Mansoura Univ., 34 (8), August, 2009

4

9025 
Helaly, M. N. et al.

Trace-elements application, overall salinity levels, increasing both these parameters throughout the experimental period during the two growing seasons. The interaction treatments showed that trace-elements applied, with the superiority of $Z n$, nullified the decreasing effect of salinity on specific leaf area and showed an additive effect to salinity one increasing leaf area ratio.

\section{Leaf area per plant:}

Table 4 shows that a significant variable differences in the leaf area per plant between the two cultivars studied in both seasons overall salinity levels and /or micronutrients treatments. Cultivar (1) had higher values than cultivar (2) throughout the experimental period of the two growing seasons. The difference among the studied two cultivars may be due to genetic variances background and to some extent, the environmental factors effect (Esmail, 1999).

Salinity decreased significantly leaf area in the two cultivars grown in both growing seasons overall trace-elements treatments. However, trace elements increased this parameter overall salinity levels during the two growing seasons with the superiority of $\mathrm{Zn}$ treatments. The highest values were recorded with plants sprayed with $\mathrm{Zn}+\mathrm{Fe}+\mathrm{Mn}$ followed by $\mathrm{Zn}+\mathrm{Fe}$, $\mathrm{Zn}+\mathrm{Mn}$ and $\mathrm{Zn}$ alone in a descending order.

Regarding the interaction effects between salinity levels, cultivars and/ or trace-elements treatments, a significant interaction effects between the three factors on leaf area of corn plant cultivars grown in the two growing seasons were recorded. Cultivar (1) abled to grow up to $5 \mathrm{dsm}^{-1}$ whereas that of cultivar (2) did not tolerate salinity overall and died even at $2.5 \mathrm{dsm}^{-1}$ without trace-elements application. The application of trace-element used induced cultivar (1) plant to tolerate more salinity up to the highest level; 7.5 $\mathrm{dsm}^{-1}$ compared with the corresponding control. In cultivar 2 only $\mathrm{Zn}$ treatments induced it tolerant to salinity but up to $5 \mathrm{dsm}^{-1}$ and the other nutrients treatments ( $\mathrm{Fe}$ and/ or $\mathrm{Mn}$ ) failed to induce this cultivar to grow under highest salinity level.

It could be concluded that trace-elements counteracted the harmful effects of salinity on decreasing leaf area depending on the cultivars examined compared with the corresponding control. Eisa (1998) reported that water stress substantially induces loss of turger which affects the rate of cell expansion and ultimate cell size, consequently decreased growth rate, stem elongation, leaf expansion and stomatal aperture.

The data obtained by Helaly et al., (2009) showed an accumulation of IAA associated with high levels of cytokinens as well as sugars in the shoots of cultivar (1) plant compared with those of cultivar (2). These results induced cultivar (1) to keep better performance against salinity and gives some sort of resistance against wilting. Such mechanism is well known as osmotic adjustment which can be accomplished by creating more negative osmotic potentials through the accumulation of the organic osmolytes (sugars and others) within the root cell as an adaptable mechanism against either biotic or abiotic stress (Hatung, 2004). Sugar as osmolytes enable plants to keep better water relation under stress conditions by increasing the ability of their roots to extract more water from even the saline soil (Hanafy Ahmed et al, 2002). 
The beneficial effects of trace element on increasing leaf area may be due to their effects on increasing cells number and size as well as water absorption (Helaly et al, 1985 a\&b). Haggag (2001) reported that foliar application of trace elements increasing the amount of metabolites synthesized per unit period and total carbohydrates. The influence of $\mathrm{Zn}$ as an activator of several oxidative enzymes (Hatung, 2004) biosynthesis of Auxins (Jeffrey, 1987) increasing photosynthesis capacity and net assimilation metabolites were recorded.

Again, the application of trace-elements as a foliar spray gave highest values than its application as a soil feeding overall salinity levels, cultivars used and/or trace-elements treatments during the two growing seasons.

\section{Stem diameter:}

In both seasons data in Table 4 shows, a significant differences in average of stem diameter were observed between the two treated cultivars. Cultivar (1) was higher in stem diameter than cultivar (2) overall salinity levels and micronutrients treatments. The differences between them were more pronounced under high salinity levels during the two growing seasons which mainly attributed to their genetic constitution rather than salinity and other treatments.

Values of stem diameter at the various sampling stages of the two cultivars examined overall micronutrients treatments revealed that stem diameter were increased continuously with age till the last sampling date taken at maturity. The highest rate of such increased was detected between the $1^{\text {st }}$ and $2^{\text {nd }}$ sampling dates indicating rapid growth during this period in all treatments of the two maize cultivars grown in both growing seasons.

With respect to the power of survival, which is taken as a criterion of salt tolerance (Richard's, 1954) the data indicated that cultivar (1) could not tolerant salinity above $5 \mathrm{dsm}^{-1}$ while cultivar (2) died at the low level, $2.5 \mathrm{dsm}^{-}$ 1 without employing any treatments from micronutrients used. The ability of cultivar (1) to tolerant salt-stress was increased up to the highest level used $\left(7.5 \mathrm{dsm}^{-1}\right)$ with the micronutrients application especially if employed as a spraying method. However, trace-element failed to improve cultivar (2) to tolerant salinity rather than $5 \mathrm{dsm}^{-1}$.

Regarding the effect of various salt levels on the stem diameter, it appeared from the same tables that there were, generally, progressive and regular decreasing effect of salinity on stem diameter and the effect was a concentration dependent; it increased with increasing salinity level. Again, it was concluded that corn plants without trace-elements application and grown under $5 \mathrm{dsm}^{-1}$ in cultivar (1) and under $2.5 \mathrm{dsm}^{-1}$ in cultivar (2) died before the $3^{\text {rd }}$ sampling date, so that they were available only for the first two samples. However under salinization, values of stem diameter of cultivar (1) were, generally, higher than those of cultivar (2), but their responses towards increasing salinity was almost similar. In addition, it was found that stem diameter of cultivar (1) was much affected by salinity than did of cultivar (2) during both growing seasons in spite of the fact that cultivar (2) could not tolerant salinity even at $2.5 \mathrm{dsm}^{-1}$. 
Helaly, M. N. et al.

Concerning the effect of micronutrients application on stem diameter, data in the same tables show that spraying method was preferable and more effective than soil feeding method overall treatments of salinity and trace elements, since all values recorded were found to be higher in sprayed-plants than that received these elements by soil feeding method. However, using trace-elements examined individually and/or in combinations increased stem diameter. The most effective treatment was found with trace element mixture, followed by $\mathrm{Zn}+\mathrm{Fe}, \mathrm{Zn}+\mathrm{Mn}, \mathrm{Zn}$ alone and the least values were recorded with $\mathrm{Mn}$ alone. None of the interactions treatments had significant effect on stem diameter during the two growing seasons. However, it showed that traceelements treatments, especially $\mathrm{Zn}$ counteracted the harmful effects of salinity on this parameter at $5 \mathrm{dsm}^{-1}$ with the two cultivars used. Moreover, salinized-plants of cultivar (2) sprayed with $\mathrm{Mn}$ and /or Fe grown under 5 $\mathrm{dsm}^{-1}$ were died similar to that of their respective control. Therefore, it could be mentioned that $\mathrm{Zn}$ treatments only had a role for induction maize plants (cultivar 2) to tolerant high salinity levels. The beneficial effect of $\mathrm{Zn}$ on growth expressed by stem diameter may be due to its effect on increasing photosynthesis area through the effects on tryptophane and auxins biosynthesis resulted in increasing photosynthesis gains (Jeffrey, 1987 and Hatung, 2004).

\section{Fresh and dry weights as well as specific leaf weight (SLW) and leaf weight ratio (LWR):}

Data in the Tables (5-7)show that there is a lower variation among dry weight than that among fresh weight in the two studied cultivars during both growing seasons. Wider variations were noted in fresh and dry weights at the two high salinity levels, whereas narrower ones were attained at the low salinity level. Moreover, it was found that fresh and dry weights of the roots, stems and leaves of the two cultivars showed a continuous increase with age till the end of the experiment; maturity. The highest rate was detected between the first two samples. Therefore, the (S) or sigmoid growth curve was detected. Moreover, the values of the root and shoot as well as whole plant fresh and dry weights of the cultivar (1) were generally higher than those of cultivar (2) but their response towards salinity and/or other treatments were almost similar.

A significant decrease in the roots, stems and leaves fresh and dry weights of both cultivars was noted with an increase in salinity level throughout the experimental period during the two growing seasons. Cultivar (2) was more influenced by salinity than cultivar (1) in this respect. In addition, the most observable effect of salinity on fresh weight content mainly on shoots. Values of root/shoot ratio (Table 10) showed significant decline in corn cultivars exposed to salinity at all stages of plant growth during the growing seasons.

As for Specific leaf weight (SLW) and leaf weight ratio (LWR) data presented in Table (7) show that, SLW and LWR trends were opposite as a result of growing corn cultivars, under different treatments of salinity, traceelements and their interactions. specific leaf weight showed gradual increase from the $1^{\text {st }}$ sample taken at the vegetative growth stage till maturity one while leaf weight ratio recorded a gradual decline with lapse of time. 
J. Agric. Sci. Mansoura Univ., 34 (8), August, 2009 
Helaly, M. N. et al.

6

9030 
J. Agric. Sci. Mansoura Univ., 34 (8), August, 2009

7

9031 
Helaly, M. N. et al.

It can be seem also that, at all stages of plant growth, salinity, overall trace elements, induce both of specific leaf weight and leaf weight ratio in all growth stages. Trace-elements showed an addition effect to salinity in both parameters studied in corn cultivars grown throughout the experimental period during the two growing seasons. The general pattern of response to the imposition of saline substrates is the suppression of fresh and dry weights which increases more or less in proportion to the solute concentration, a trend that seems to agree with the results obtained in the present investigation.

Hatung (2004) reported that the primary effect of high salinity levels is to reduce considerably net photosynthesis rate per unit leaf area and/or increasing respiration rate. Similarly, Jeffrey (1987) attributed the reduction in fresh and dry weights of the plants, due to salinity, to its effect on increasing respiration rates. Both reasons may be operative simultaneously.

The results also indicated that fresh and dry weights of the untreated control plants were decreased sharply with increasing salinity level. However, slight increase in dry weight of untreated plants was observed at the low salinity level especially with cultivar (1). Again, cultivar (2) was more affected by salinity than did in cultivar (1). The effect of salinity had been widely attributed to antagonism between ions in their absorption especially at the higher salinity level (Hatung, 2004).

Regarding the effect of trace-elements, data in the same tables show that almost the various treatments had significant effect on increasing fresh and dry weights of the roots, stems and leaves as well as whole plant of in the two cultivars studied throughout the experimental period during the two growing seasons. Similarly, salinity increased both of SLW and LWR. Zn alone or in combination with other trace-elements used recorded high values in this respect. Fe treatment, however, produced a less increase values than the other treatments used. Similar trend was recorded with the two cultivars studied during the two growing seasons. The same data indicated that no significant difference was detected between the two application methods used with; trace-elements spraying or soil feeding. However, spraying method produced high growth weight than did receive the same element as a soil feeding throughout the experimental period during the two growing seasons. Again, $\mathrm{Zn}$ treatments produced high values whereas, using $\mathrm{Fe}$ alone produced a less values in this respect. The growth restoration capacity of these treatments was much more pronounced at the highest level of salinity.

Regarding the interaction effects between salinity and trace elements, it was found that all trace elements used specially with $\mathrm{Zn}$ counteracted to one degree or another the depressing effect of salinity on plant growth depending on the salinity level and cultivars used throughout the experiment period during the two growing seasons. At the $3^{\text {rd }}$ sampling date, untreated plants of cultivar (2) died and failed to grow under $2.5 \mathrm{dSm}^{-1}$ salinity level whereas that of cultivar (1) tolerate salinity up to $5 \mathrm{dSm}^{-1}$. Trace elements treatments induced plants of cultivar (1) to tolerate all salinity levels used throughout the experimental period during the two growing seasons. $\mathrm{Zn}$ alone or in combination gave the best results in this respect. Similarly, trace-elements 
used induced plants of cultivar (2) to tolerate salinity but only up to the second sampling date. In the $3^{\text {rd }}$ sampling date, it was found that treated of cultivar (2) with the trace elements used counteracted the harmful effect of the low salinity level $\left(2.5 \mathrm{dSm}^{-1}\right)$ only and failed to induce the plants to tolerate more salinity levels. However, $\mathrm{Zn}$ treatments (alone or in combination) not only counteracted the harmful effect of salinity at $5 \mathrm{dSm}^{-1}$, but also showed an additive effect in this respect. Better counteraction effect was achieved at $2.5 \mathrm{dSm}^{-1}$ level and these effects were pronounced in dry weight than fresh weight especially at the two high salinity levels during the two growing seasons. The best treatment restoring most of the plant growthcapacity represented by fresh and dry weights of the roots as well as the shoots under salinity was $\mathrm{Zn}+\mathrm{Fe}+\mathrm{Mn}$. It is effect in counteracting salinity was particularly evident under the two high salinity levels. This may suggest that corn plant subjected to this treatment acquired a good salt tolerance capacity and the importance of trace elements especially $\mathrm{Zn}$ for plant growth. It seems that $\mathrm{Zn}$ treatments improved the plant salt tolerance capacity through their increasing effects on tryptophane and IAA synthesis. In this context, Singh et al (1990 b) found that IAA increased the dry weight of shoots and grain yield of wheat under saline condition up to $12 \mathrm{mho} / \mathrm{cm}$. Ayoub (1975) reported that dry weight of beans was positively correlated with high $\mathrm{Ca}$ application rate and negatively correlated with the Na contents in the irrigation water and plant tissues.

From the previous results it could be concluded that all growth studied of corn plants were decreased as the salinity level increased. These results might be ascribed to the high osmotic pressure of soil solution, which restricted the absorption of water by plant root and/or to the toxic effects of certain ions in soil solution and their effects on photosynthetic rates, translocation and migration of metabolic to the different plant organs and finally on the dry weight content of the various organs of corn cultivars plants. Besides, salinity has been shown to reduce the synthesis of DNA, RNA and protein in many plants, which might lead to disturbance in metabolic activities, cell division and elongations and the activities of the mitochondria and chloroplasts were reduced. These explanation, were supported by Helaly (1984), Helaly et al (1985 a\&b), Ghallab and Nesiem (1999) and Ghallab and El-Ghadban (2003 \& 2004) and Perrey et al (1983) found that the effects of stress condition mainly due to the reduction of net photosynthesis and increasing photorespiration ratio. Mohamed (1976) stated that stress inhibited growth of wheat as a result of the decrease in net assimilation rate. Hayward and Long (1943) noticed that water stress caused by high osmotic potential decreased activities of meristematic and cambial cells and led to a maturation of small cell size. El-Dodo (1976) found that water stress was a direct effect on the reduction in dry weight content of all sesame organs which was accumulative of reduced plant size, reduced number of roots and laves as well as total leaf area. He added that, reduction of growth under water stress reflects metabolic insufficiency resulting from relative unavailability of water and minerals. El-Shafey et al (2003) stated that when plants are subjected to water stress certain physiological responses including wilting and stomatal closure usually enhanced rates of leaf senescence and therefore, decreased 
net assimilation rate and plant growth. They added that, all these processes might be attributed to hormonal changes in addition to other factors such as minerals deficiencies and dehydration. The relation between the onset of water stress and the elevation of $\mathrm{AbA}$ level in maize leaf tissues has been previously demonstrated (Beardsell and Cohen, 1975). It seems that, AbA present in stressed leaves may move from the mesophyl to the gard cells in response to stress and this induce stomatal closure.

Trace-elements application counteracted the harmful effects of salinity in the two cultivars of corn under the present investigation. $\mathrm{Zn}$ was the best one in this respect. Jeffrey (1987) reported that $\mathrm{Zn}$ enhanced the biosynthesis of auxins within the plant tissues which are known to affect on macromolecules synthesis for polyamines and increase nucleic acids synthesis and stimulate various processes associated with the synthesis of protein and promotion of cell division.

The ability of cultivar (1) to tolerant salinity more than cultivar (2) may be to the genetical variance between the two cultivars (Esmail, 1999).

\section{REFERENCES}

Ayoub, A.T. (1975). Effect of calcium on sodium salinization of beans (Phaseolus vulgaris, L.). J. Exp. Bot. 25(85): 245-252.

Beardsell, M.F. and D. Cohen (1975). Relationships between leaf water status, abscisic acid levels and stomatal resistance in maize and sorghum. Plant Physiol., 56: 207-212.

Chyung Van-Lung and L.P. Lapine (1975). Photosynthetic intensity and productivity in plants under saline condition. Sel Skokhozyal Stvennaya Biologiya, 9(3): 381-384. (c.f. Hort. Abs., 45(1): 327)

Eisa, G.S. (1998). Botanical studies on sesame plant. M. Sc. Thesis, Faculty of Agric. Zagazig Univ., Egypt

El-Dodo, M.K. (1976). Some physiological studies on sesame plant (Sesamum indicum, L) in relation to its water requirements. M. Sc. Thesis, Fac. Agric. Cairo Univ. Egypt.

El-Shafey, Y. H.; S. M. Salem; O. M. El-Shihy: A. M. Ghallab and Hanaa F. Y. Mohamed (2003). Effect of gamma rays, abscisic acid and putrescine on production of wheat plants more tolerant to salinity: B- in vitro callus induction, plant regeneration, and grains production under saline conditions. J. Agric. Sci. Mansoura Univ., 28(5): 3551-3570.

Esmail, H.E. (1999). A preliminary study on the effect of some cultural practices on growth and yield of some yellow maize cultivars. M. Sc. Thesis, Faculty of Agric. Mansoura Univ., Egypt.

Ghallab, A.M. and M.R.A. Nesiem (1999). Effect of Foliar application of titanium on growth, chemical composition and productivity of soybean and wheat plants growing under different levels of NPK fertilization J. Agric. Sci Mansoura Univ., 24(2): 605-623.

Ghallab, A.M. and A.E. El-Ghadban (2003). Reinforcing salt tolerance of Mrjoram plants by foliar application of putrescine. J. Agric. Sci., 28(4): 2651-2669, Mansoura Univ. Egypt.

Ghallab, A.M. and A.E. El-Ghadban (2004). Physiological response of Marjoram plants to biofertilizer and organic fertilization. J. Agric. Sci., 29(4): 1743-1759, Mansoura Univ., Egypt.

Gomez, K. A. and A. A. Gomez (1984). Statistical Procedures for Agriculture Research. $2^{\text {nd }}$ Ed. John Wiley and Sons. pp. 680. 
Haggag, A.E. (2001). The salt tolerance of some important Egyptian crops. Ph. D. Thesis, Fac. Agric. Mansoura Univ., Egypt.

Hanafy Ahmed, S.M.; S.M. Mandour; A.M. Ghallab and G.A. Diab (2002). Effect of nitrogen, potassium and micronutrients fertilization on the growth, yield and chemical composition of some sorghum cultivars growing under saline and sandy soil conditions. $2^{\text {nd }}$ Congress of Recent Technologies in Agric., Giza, 28-30 Oct. IV: 876-900.

Hatung, W. (2004). Plant response to stress: Abscisic acid fluxes. Marcel Dekker Inc., New York. pp. 540-690.

Hayward, W.E. and E.M. Long (1943). Some effects of sodium salts on the growth of the tomato. Plant Physiol., 18(4): 556-569.

Helaly, M.N.M. (1972). Studies on the effects of salinity on germination, growth and chemical composition of Egyptian henbane (Hyoscyamus muticus, L.). M. Sc. Thesis, Faculty of Agric. Cairo Univ., Egypt.Helaly, M.N.M. (1984). Effects of salinity on the chloroplast ultraculture and photosynthetic activity in horse been plants. J. Agric. Sci., 9: 241-250, Mansoura Univ., Egypt

Helaly, M.N.M.; S.Z.M. El-Basyouni and A.A. Arafa (1985 a). Physiological studies on salt tolerance in chamomile plant. $2^{\text {nd }}$ Conf. Agric. Botany Sci., 21-24 Sept., 1: 125-148, Mansoura Univ., Egypt.

Helaly, M.N.M.; S.Z.M. El-Basyouni and A.M. Salama (1985 b). Morphological and physiological studies on petunia plants. $2^{\text {nd }}$ Conf. Agric. Bot. Sci. 21-24 Sept. Fac. of Agric. Mansoura Univ. Egypt.

Helaly, M.N.M.; A.A. Arafa; R.A. Fouda and H.F. Esmail (2009). Response of two newly developed corn genotypes (Zea nays. L.) to some trace elements under salt stress throughout their growth life span. 2Endogenous phytohormonas. J. Agric. Sci Mansoura Univ., In Press.

Jackson, M.L. (1973). Soil Chemical analysis. Prentice-Hall of India private. New Delhi, pp. 144-197.

Jeffrey, W.D. (1987). Soil Plant Relationships, An Ecological Approch. Groom Helm Ltd., Provident House, Bunel Row Backenham, Kenl BR3 IAT.

Johanson, R.E. (1967). Comparison of methods for estimating cotton leaf area. Agron. Jour. 59: 493-494.

Magelhaes P.C.; Duraes F.O.M. and Schaffert R.E. (2000). Physiology of sorghum plant. Embrapa Milho Sorgo Circular Tecnica, Embrapa Milho Sorgo (2000), 3: 46 pp. (c.f. Field Crop Abst., 54 (12): 7958,2001).

Marschner, H. (1995). Mineral Nutrition of Higher Plants. $2^{\text {nd }}$ ed., Academic press, London, New York. 360-396.

Mohamed, A.M. (1976). Effect of soil moisture stress on photosynthetic efficiency, growth and grain quality of wheat. M. Sc. Thesis, Fac. of Agric. Ain-Shams Univ., Egypt.

Nuttall, J.; R. Armstrong and D. Connor (2003). The effects of salinity, sodicity and soluble boron on wheat yields in the Victorian Southern Malle. Proc. of the 11 Australian Agron. Conference, Geelong.,pp. 1-6.

Page, A.I.; R.H. Miller and T.R. Keeney (1982). Methods of soil analysis part 2. Amer. Soc. Agric. Inc. Madison Wig: 595.

Perrey, S.W.; D.R. Krieg and R.B. Hutmacher (1983). Photosynthetic rate control in cotton. Plant Physiol., 73(3): 662-65.

Peynado, A. and R.H. Young (1968). Moisture changes in intact leaves monitored by guage technique. Proc. Amer. Soc. Hort. Sci., 92: 211220.

Piper, C.S. (1950). Soil and plant analysis. Inter-Sci. Publ., Inc., New York Univ. Adelaide, Adelaide.

Richard's, L. A. (Ed) (1954). Diagnosis and improvement of saline and alkali soils. Agric. Handbook No. 6, U.S. Dept of Agric. 
Helaly, M. N. et al.

Singh, K.N.; D.K. Sharma and R.K. Chillar (1990 b). Effect of soil salinity on the yield, chemical composition and uptake of nutrients by Jowar (Sorghum bicolor) cultivars grown for fodder. Annals of Agric. Res., 11(3-4): 233-240. (C.F. Field Crop Abs., 55: 2277).

\section{تأثثر بعض العناصر الصغرى علي صنفين جايلين من الذرة الثامية تحت ظروف الملوحة خلال دورة حياة نموهما الصني

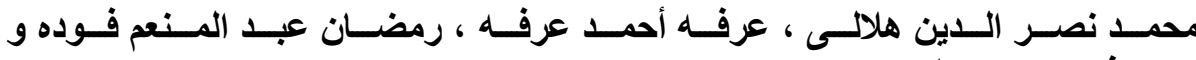

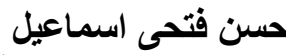 قسم النبات ازراعى كلية الزراعة جامعة المنصورة}

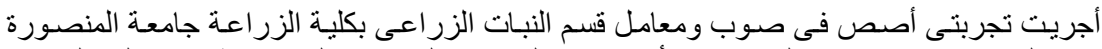

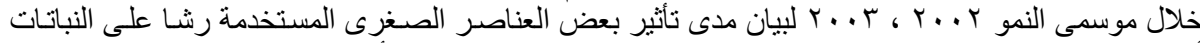

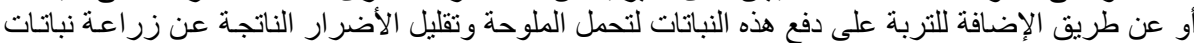

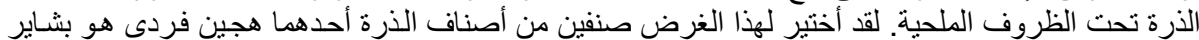

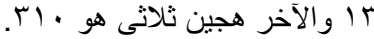

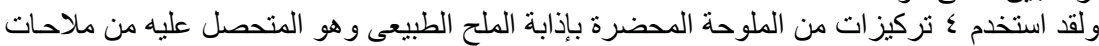

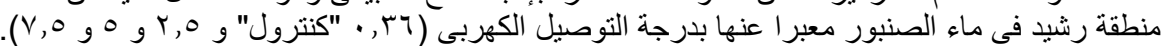

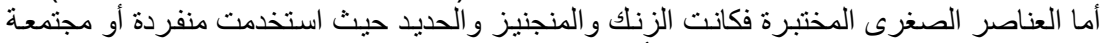

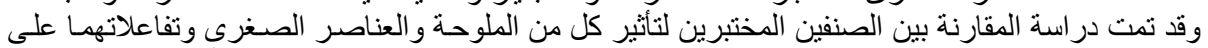

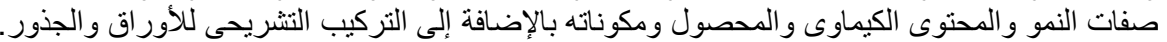

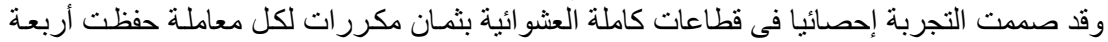

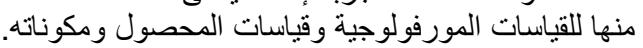

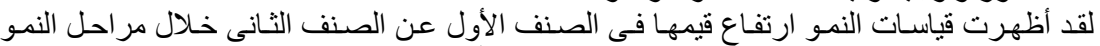

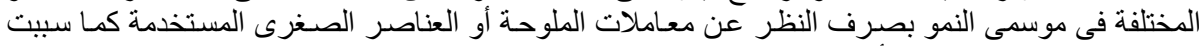

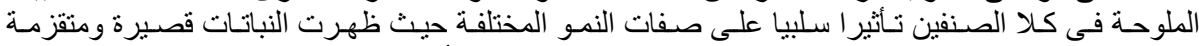

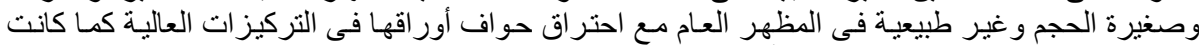

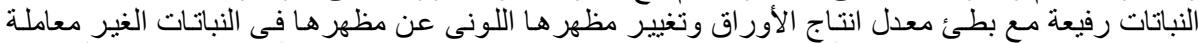

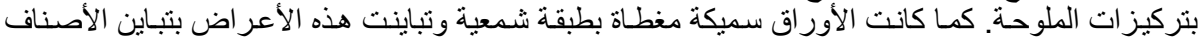

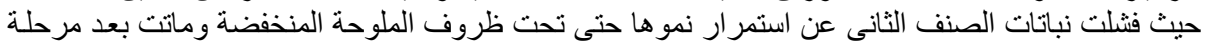

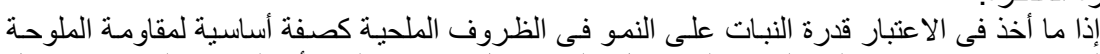

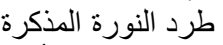

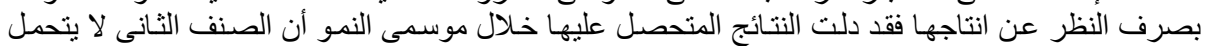

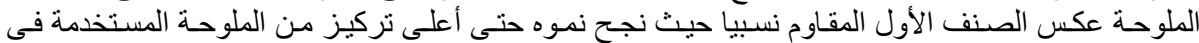
التجربة باستخدام بعض معاملات العناصر الصغار الصغرى.

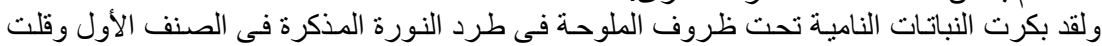

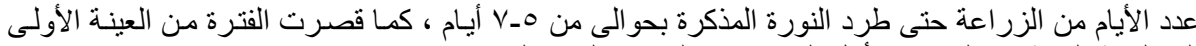

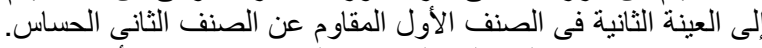

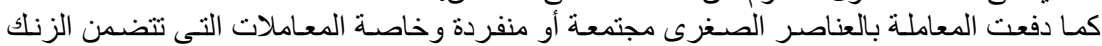

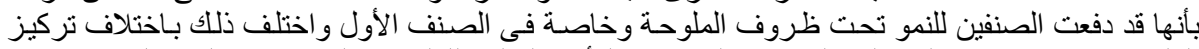

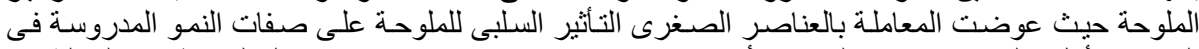

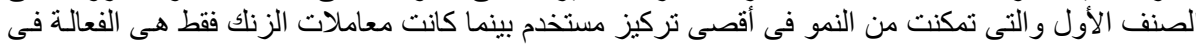

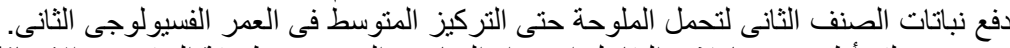

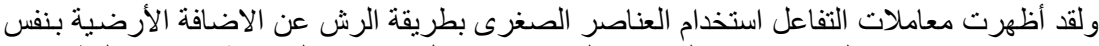

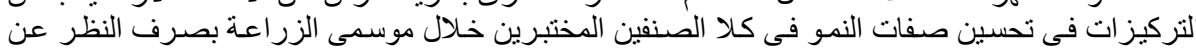
الملوحة المستخدمة أو معاملات العناصر الصغئ الصغرى.

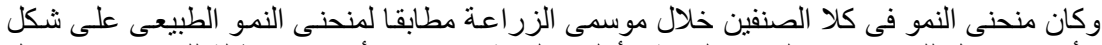

حرف S و أقصى معدل للنمو تم تسجيله بين الصفة الأولى والثانية فيما كانت أقصى استطالة للسناق بعد اكتمال

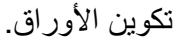


Table (3): Root length (cm), number of adventitious roots, plant height $(\mathrm{cm})$ and days to the beginning of tasseling of corn plant as affected by cultivars, salinity levels, trace-elements treatments and application methods throughout the experimental period at 35 (A1), 65 (A2) and 115 (A3) days from sowing during the two growing seasons of 2002 and 2003.

\begin{tabular}{|c|c|c|c|c|c|c|c|c|c|c|c|c|c|c|c|c|c|c|c|c|}
\hline \multirow{2}{*}{$\begin{array}{l}\text { Characters } \\
\text { Treatments }\end{array}$} & \multicolumn{6}{|c|}{ Root length } & \multicolumn{6}{|c|}{ Number of adventitious roots } & \multicolumn{6}{|c|}{ Plant height } & \multicolumn{2}{|c|}{$\begin{array}{l}\text { Days to the } \\
\text { beginning of } \\
\text { tasseling }\end{array}$} \\
\hline & \multicolumn{2}{|c|}{\begin{tabular}{|c|} 
A1 \\
20025033
\end{tabular}} & \multicolumn{2}{|c|}{\begin{tabular}{|c|c|} 
A2 \\
2002
\end{tabular}} & \multicolumn{2}{|c|}{ A3 } & \multicolumn{2}{|c|}{ A1 } & \multicolumn{2}{|c|}{ A2 } & \multicolumn{2}{|c|}{ A3 } & \multicolumn{2}{|c|}{ A1 } & \multicolumn{2}{|c|}{ A2 } & \multicolumn{2}{|c|}{\begin{tabular}{|c|c|} 
A3 \\
2002 & 2003 \\
\end{tabular}} & 2002 & 2003 \\
\hline $\begin{array}{l}\text { A- Cultivars: } \\
\text { C1 } \\
\text { C2 } \\
\end{array}$ & \begin{tabular}{|l|}
7.2 \\
6.9 \\
\end{tabular} & $\begin{array}{l}7.8 \\
7.4 \\
\end{array}$ & \begin{tabular}{|l|}
21.1 \\
16.0 \\
\end{tabular} & \begin{tabular}{|l|}
21.6 \\
16.4 \\
\end{tabular} & \begin{tabular}{|l|}
22.0 \\
13.2 \\
\end{tabular} & \begin{tabular}{|l|}
22.5 \\
13.3 \\
\end{tabular} & $\begin{array}{l}6.1 \\
5.2 \\
\end{array}$ & \begin{tabular}{|l|}
6.4 \\
5.3 \\
\end{tabular} & \begin{tabular}{|l|}
14.5 \\
12.0
\end{tabular} & $\begin{array}{l}15.0 \\
12.4\end{array}$ & \begin{tabular}{|c|}
14.5 \\
8.9
\end{tabular} & $\begin{array}{c}15.1 \\
9.2\end{array}$ & $\begin{array}{l}7.2 \\
6.9\end{array}$ & $\begin{array}{l}7.8 \\
7.4\end{array}$ & \begin{tabular}{|l|}
21.1 \\
16.0
\end{tabular} & \begin{tabular}{|l|}
21.6 \\
16.4
\end{tabular} & \begin{tabular}{|l|}
22.0 \\
13.2
\end{tabular} & \begin{tabular}{|l|}
22.5 \\
13.3 \\
\end{tabular} & $\begin{array}{l}57 \\
55\end{array}$ & $\begin{array}{l}58 \\
57\end{array}$ \\
\hline $\begin{array}{c}\text { B- Salinity Levels }\left(\mathbf{D s m}^{-1}\right) \\
\text { Control } \\
2.5 \\
5.0 \\
7.5 \\
\text { Lsd at } 5 \%\end{array}$ & \begin{tabular}{|l|}
9.2 \\
7.5 \\
6.2 \\
5.3 \\
0.1
\end{tabular} & $\begin{array}{l}9.8 \\
7.9 \\
6.7 \\
6.0 \\
0.1 \\
\end{array}$ & \begin{tabular}{|c|}
22.9 \\
19.8 \\
16.8 \\
14.6 \\
0.3
\end{tabular} & $\begin{array}{c}23.6 \\
20.4 \\
17.2 \\
14.9 \\
0.3\end{array}$ & \begin{tabular}{|c|}
25.0 \\
22.2 \\
14.6 \\
8.4 \\
0.3
\end{tabular} & \begin{tabular}{|c}
25.7 \\
22.5 \\
14.7 \\
8.7 \\
0.2
\end{tabular} & $\begin{array}{l}7.4 \\
6.0 \\
5.2 \\
4.1 \\
0.2\end{array}$ & \begin{tabular}{|l|}
7.8 \\
6.2 \\
5.3 \\
4.2 \\
0.2
\end{tabular} & $\begin{array}{c}15.6 \\
14.0 \\
12.4 \\
11.0 \\
0.4\end{array}$ & $\begin{array}{c}16.2 \\
14.4 \\
13.0 \\
11.2 \\
0.3\end{array}$ & \begin{tabular}{|c|}
16.3 \\
14.7 \\
10.1 \\
5.7 \\
0.4
\end{tabular} & \begin{tabular}{|c|}
17.1 \\
15.2 \\
10.6 \\
5.7 \\
0.3 \\
\end{tabular} & $\begin{array}{l}9.2 \\
7.5 \\
6.2 \\
5.3 \\
0.1\end{array}$ & $\begin{array}{l}9.8 \\
7.9 \\
6.7 \\
6.0 \\
0.1\end{array}$ & \begin{tabular}{|c|}
22.9 \\
19.8 \\
16.8 \\
14.6 \\
0.3 \\
\end{tabular} & $\begin{array}{c}23.6 \\
20.4 \\
17.2 \\
14.9 \\
0.3\end{array}$ & \begin{tabular}{|c}
25.0 \\
22.2 \\
14.6 \\
8.4 \\
0.3
\end{tabular} & \begin{tabular}{|c|}
25.7 \\
22.5 \\
14.7 \\
8.7 \\
0.2
\end{tabular} & \begin{tabular}{|c|}
63 \\
60 \\
51 \\
49 \\
0.27
\end{tabular} & $\begin{array}{c}65 \\
61 \\
53 \\
51 \\
0.23\end{array}$ \\
\hline $\begin{array}{c}\text { C- TREATMENTS: } \\
\text { Control } \\
\mathrm{Zn} \\
\mathrm{Mn} \\
\mathrm{Fe} \\
\mathrm{Zn}+\mathrm{mn} \\
\mathrm{Zn}+\mathrm{fe} \\
\mathrm{Mn}+\mathrm{fe} \\
\mathrm{Zn}+\mathrm{mn}+\mathrm{fe} \\
\text { Lsd at } 5 \%\end{array}$ & \begin{tabular}{|l|}
4.7 \\
7.7 \\
6.3 \\
5.7 \\
8.6 \\
7.5 \\
7.0 \\
9.2 \\
0.2 \\
\end{tabular} & \begin{tabular}{|l|}
5.2 \\
8.2 \\
6.7 \\
6.2 \\
9.2 \\
8.1 \\
7.6 \\
9.7 \\
0.2 \\
\end{tabular} & $\begin{array}{c}13.5 \\
20.1 \\
17.0 \\
16.0 \\
21.5 \\
20.7 \\
18.2 \\
21.1 \\
0.4\end{array}$ & $\begin{array}{c}14.0 \\
20.7 \\
17.4 \\
16.6 \\
22.0 \\
21.2 \\
18.8 \\
21.5 \\
0.4\end{array}$ & \begin{tabular}{|c|}
10.8 \\
20.9 \\
15.4 \\
15.3 \\
21.1 \\
20.3 \\
16.0 \\
20.6 \\
0.4
\end{tabular} & $\begin{array}{c}11.2 \\
20.8 \\
15.8 \\
15.7 \\
21.6 \\
20.6 \\
16.2 \\
21.3 \\
0.4\end{array}$ & $\begin{array}{l}4.6 \\
5.9 \\
4.8 \\
4.0 \\
6.8 \\
7.1 \\
4.9 \\
7.3 \\
0.3\end{array}$ & \begin{tabular}{|l|}
4.6 \\
6.4 \\
4.9 \\
4.2 \\
7.4 \\
6.9 \\
5.3 \\
7.1 \\
0.3 \\
\end{tabular} & \begin{tabular}{|c|}
9.1 \\
15.4 \\
11.3 \\
8.6 \\
16.1 \\
16.1 \\
11.9 \\
17.3 \\
0.5 \\
\end{tabular} & \begin{tabular}{|c|}
9.6 \\
16.2 \\
11.7 \\
9.0 \\
16.9 \\
16.1 \\
12.2 \\
17.6 \\
0.5 \\
\end{tabular} & \begin{tabular}{|c|}
7.0 \\
14.4 \\
9.3 \\
7.6 \\
14.8 \\
14.8 \\
9.7 \\
16.1 \\
0.5 \\
\end{tabular} & \begin{tabular}{|c|}
7.4 \\
14.9 \\
9.8 \\
8.4 \\
15.5 \\
15.1 \\
10.1 \\
16.0 \\
0.4 \\
\end{tabular} & $\begin{array}{l}4.7 \\
7.7 \\
6.3 \\
5.7 \\
8.6 \\
7.5 \\
7.0 \\
9.2 \\
0.2\end{array}$ & $\begin{array}{l}5.2 \\
8.2 \\
6.7 \\
6.2 \\
9.2 \\
8.1 \\
7.6 \\
9.7 \\
0.2\end{array}$ & $\begin{array}{c}13.5 \\
20.1 \\
17.0 \\
16.0 \\
21.5 \\
20.7 \\
18.2 \\
21.1 \\
0.4\end{array}$ & \begin{tabular}{|c}
14.0 \\
20.7 \\
17.4 \\
16.6 \\
22.0 \\
21.2 \\
18.8 \\
21.5 \\
0.4
\end{tabular} & $\begin{array}{c}10.8 \\
20.9 \\
15.4 \\
15.3 \\
21.1 \\
20.3 \\
16.0 \\
20.6 \\
0.4\end{array}$ & $\begin{array}{c}11.2 \\
20.8 \\
15.8 \\
15.7 \\
21.6 \\
20.6 \\
16.2 \\
21.3 \\
0.4\end{array}$ & \begin{tabular}{|c|}
31 \\
61 \\
58 \\
57 \\
61 \\
60 \\
57 \\
62 \\
0.38 \\
\end{tabular} & $\begin{array}{c}31 \\
63 \\
59 \\
58 \\
63 \\
62 \\
59 \\
63 \\
0.32 \\
\end{array}$ \\
\hline $\begin{array}{c}\text { D- Application methods: } \\
\text { Foliar } \\
\text { Ground } \\
\end{array}$ & \begin{tabular}{|l|}
7.6 \\
6.6 \\
\end{tabular} & $\begin{array}{l}8.1 \\
7.1 \\
\end{array}$ & \begin{tabular}{|l|}
19.4 \\
17.6 \\
\end{tabular} & \begin{tabular}{|l|}
20.0 \\
18.1 \\
\end{tabular} & \begin{tabular}{|l|}
18.6 \\
16.5 \\
\end{tabular} & \begin{tabular}{|l|}
18.9 \\
16.9 \\
\end{tabular} & $\begin{array}{l}6.2 \\
5.1 \\
\end{array}$ & \begin{tabular}{|l|}
6.5 \\
5.2 \\
\end{tabular} & \begin{tabular}{|l|}
14.0 \\
12.5 \\
\end{tabular} & \begin{tabular}{|l|}
14.4 \\
12.9 \\
\end{tabular} & \begin{tabular}{|l|}
13.8 \\
11.1 \\
\end{tabular} & \begin{tabular}{|l|}
12.7 \\
11.6 \\
\end{tabular} & \begin{tabular}{|l|}
7.6 \\
6.6 \\
\end{tabular} & $\begin{array}{l}8.1 \\
7.1 \\
\end{array}$ & \begin{tabular}{|l|}
19.4 \\
17.6 \\
\end{tabular} & \begin{tabular}{|l|}
20.0 \\
18.1 \\
\end{tabular} & \begin{tabular}{|l}
18.6 \\
16.5 \\
\end{tabular} & \begin{tabular}{|l|}
18.9 \\
16.9 \\
\end{tabular} & $\begin{array}{l}57 \\
55 \\
\end{array}$ & $\begin{array}{l}58 \\
57 \\
\end{array}$ \\
\hline $\begin{array}{c}\text { E- Interactions: } \\
A \times B \\
A \times C \\
B \times C \\
A \times B \times C \\
A \times D \\
B \times D \\
A \times B \times D \\
C \times D \\
A \times C \times D \\
B \times C \times D \\
A \times B \times C \times D \\
\end{array}$ & $\begin{array}{l}\text { ** } \\
\text { ** } \\
\text { ** } \\
\text { ** } \\
* \\
* \\
* \\
\text { * } \\
\text { * } \\
\text { * } \\
\text { * }\end{array}$ & $\begin{array}{l}\text { ** } \\
\text { ** } \\
\text { ** } \\
\text { ** } \\
* \\
* \\
* \\
* \\
* \\
* \\
\text { * } \\
\text { * }\end{array}$ & $\begin{array}{c}* * \\
* * \\
* * \\
* * \\
N S \\
* * \\
* \\
* * \\
* \\
* \\
* \\
*\end{array}$ & $\begin{array}{c}* * \\
* * \\
* * \\
* * \\
N S \\
* \\
* \\
* * \\
\text { NS } \\
* \\
\text { NS }\end{array}$ & $\begin{array}{c}* * \\
* * \\
* * \\
* * \\
* * \\
* * \\
\mathrm{NS} \\
* * \\
* * \\
* * \\
* *\end{array}$ & $\begin{array}{c}* * \\
* * \\
* * \\
* * \\
* * \\
* * \\
N S \\
* \\
* \\
* \\
* \\
*\end{array}$ & $\begin{array}{c}* * \\
* * \\
* * \\
* * \\
* * \\
* \\
* \\
* * \\
N S \\
* \\
* \\
\end{array}$ & $\begin{array}{c}* * \\
* * \\
* * \\
* * \\
N S \\
* * \\
N S \\
* * \\
* \\
N S \\
* \\
\end{array}$ & $\begin{array}{c}N S \\
* * \\
* * \\
* \\
* \\
* \\
* * \\
* \\
* \\
* * \\
*\end{array}$ & $\begin{array}{c}N S \\
* * \\
* * \\
* * \\
* \\
* \\
N S \\
* \\
* * \\
* \\
* \\
\end{array}$ & $\begin{array}{l}\text { ** } \\
\text { ** } \\
\text { ** } \\
\text { ** } \\
\text { * } \\
* \\
\text { * } \\
\text { * } \\
\text { * } \\
\text { ** } \\
\text { * }\end{array}$ & $\begin{array}{c}* * \\
* * \\
* * \\
* * \\
N S \\
* * \\
N S \\
* * \\
* * \\
* * \\
* *\end{array}$ & $\begin{array}{l}* \\
* * \\
* * \\
* * \\
* * \\
* \\
* \\
* \\
* \\
* \\
* \\
* \\
*\end{array}$ & $\begin{array}{l}\text { ** } \\
\text { ** } \\
\text { ** } \\
\text { ** } \\
* \\
* \\
* \\
* \\
* \\
* \\
* \\
* \\
*\end{array}$ & \begin{tabular}{c|}
$* *$ \\
$* *$ \\
$* *$ \\
$* *$ \\
$N S$ \\
$* *$ \\
$*$ \\
$*$ \\
$*$ \\
$*$ \\
$*$ \\
$*$ \\
\end{tabular} & $\begin{array}{c}* * \\
* * \\
* * \\
* * \\
N S \\
* \\
* \\
* \\
* \\
N S \\
* \\
\text { NS }\end{array}$ & $\begin{array}{l}* * \\
* * \\
* * \\
* * \\
* * \\
* * \\
\text { NS } \\
* * \\
* * \\
* * \\
* * \\
\text { ** }\end{array}$ & $\begin{array}{c}\text { ** } \\
* * \\
* * \\
* * \\
* * \\
* * \\
\text { NS } \\
* \\
* \\
* * \\
* \\
\text { * }\end{array}$ & $\begin{array}{c}* * \\
* * \\
* * \\
* * \\
\text { NS } \\
* \\
\text { NS } \\
* \\
\text { NS } \\
* * \\
* \\
\end{array}$ & $\begin{array}{l}* * \\
* * \\
\star * \\
* * \\
* \\
* * \\
* \\
* * \\
* \\
* \\
* \\
\end{array}$ \\
\hline
\end{tabular}


Table (4): Leaf area/plant $\left(\mathrm{cm}^{2} \times 10\right)$, specific leaf area, leaf area ratio and stem diameter of corn plant as affected by cultivars, salinity levels, trace-elements treatments and application methods throughout the experimental period at 35 (A1), 65 (A2) and 115 (A3) days from sowing during the two growing seasons of 2002 and 2003.

\begin{tabular}{|c|c|c|c|c|c|c|c|c|c|c|c|c|c|c|c|c|c|c|c|c|c|c|c|c|}
\hline \multirow{3}{*}{$\begin{array}{l}\text { Characters } \\
\text { Treatments }\end{array}$} & \multicolumn{6}{|c|}{ Leaf area $(\mathrm{cm} 2 \times 10) /$ plant } & \multicolumn{6}{|c|}{ Specific leaf area (SLA) } & \multicolumn{6}{|c|}{ Leaf area ratio (LAR) } & \multicolumn{6}{|c|}{ Stem diameter } \\
\hline & \multirow{2}{*}{\multicolumn{2}{|c|}{\begin{tabular}{|r|r|} 
A1 \\
2002 & 20 \\
\end{tabular}}} & \multirow{2}{*}{\multicolumn{2}{|c|}{$\begin{array}{c}\text { A2 } \\
02\end{array}$}} & \multirow{2}{*}{\multicolumn{2}{|c|}{\begin{tabular}{|c|c|}
\multicolumn{1}{|c|}{ A3 } \\
2002 & 2003 \\
\end{tabular}}} & \multirow{2}{*}{\multicolumn{2}{|c|}{ A1 }} & \multicolumn{2}{|c|}{ A2 } & \multirow{2}{*}{\multicolumn{2}{|c|}{$\begin{array}{c}\text { A3 } \\
02 \mid 20\end{array}$}} & \multicolumn{2}{|c|}{ A1 } & \multicolumn{2}{|c|}{ A2 } & \multirow{2}{*}{\multicolumn{2}{|c|}{\begin{tabular}{|c|} 
A3 \\
20022003
\end{tabular}}} & \multicolumn{2}{|r|}{ A1 } & \multirow{2}{*}{\multicolumn{2}{|c|}{ A2 }} & \multirow{2}{*}{\multicolumn{2}{|c|}{$\begin{array}{c}\text { A3 } \\
32002200\end{array}$}} \\
\hline & & & & & & & & & & 22003 & & & & 2003 & & 2003 & & & & & & & & \\
\hline c & 586 & 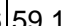 & 973 & 979 & 1037 & 1044 & 290 & 288 & 197 & 195 & 1110 & 110 & 0.981 & 10955 & 78 & 780 & 055 & 0548 & 08 & $3 \mid 087$ & 11 & & 18 & \\
\hline $\mathrm{C}$ & 43.5 & 44.1 & 87.7 & 88.6 & 66.1 & 66.8 & 3.26 & 3.22 & 2.07 & 2.08 & 0.75 & 0.74 & 1.035 & 51.006 & 0.883 & .875 & 5.412 & .408 & 0.5 & 0.55 & 0.7 & 0.77 & 0.9 & 0.99 \\
\hline \multicolumn{25}{|c|}{ B-Salinity Levels(Dsm") } \\
\hline Control & 56.6 & 57.1 & 103.1 & 103.8 & 3115.1 & 116.0 & 2.28 & 2.26 & 1.87 & 1.88 & 1.19 & $\begin{array}{l}9 \\
9\end{array}$ & 0.863 & 30.842 & 20.796 & 0.789 & 90.617 & 70.615 & $\begin{array}{lll}5 & 0.8\end{array}$ & 30.91 & 1.1 & 1.22 & 1.9 & 2.09 \\
\hline 2.5 & 53.2 & 53.6 & 99.4 & 100.0 & 104.9 & 105.6 & 2.66 & 2.63 & 1.98 & 1.96 & 1.13 & \begin{tabular}{l|l|}
3 & $1.11 \quad r \quad r$
\end{tabular} & 0.964 & $4 \mid 0.930$ & $\mid 0.849$ & 0.839 & 90.597 & 70.5 & 0.6 & 0.74 & 0.9 & 1.05 & 1.7 & 1.81 \\
\hline $5 .($ & & 50.0 & 89.2 & 90.0 & 75.1 & 75.6 & 3.80 & 3.76 & 2.11 & 2.11 & 0.84 & \begin{tabular}{l|l}
4 & 0.84
\end{tabular} & 1.093 & 31.0 & 0.853 & & 50.445 & 50.443 & $\begin{array}{ll}3 & 0.6\end{array}$ & 0.68 & \begin{tabular}{l|l}
3 & 0.8
\end{tabular} & 0.89 & 1.2 & 1.27 \\
\hline 7. & 45.0 & 45.7 & 78.3 & 79.2 & 44.7 & 45.2 & 3.59 & 3.54 & 2.12 & 2.12 & 0.52 & $\begin{array}{ll}2 & 0.52\end{array}$ & 1.112 & 21.082 & 20.845 & 50.8 & 6.265 & 50.2 & $\begin{array}{ll}5 & 0.5\end{array}$ & 50.52 & 0.7 & 0.72 & 0.7 & 0.78 \\
\hline Lsd at $5 \%$ & 0.23 & 0.30 & 0.26 & 0.33 & 0.22 & 0.32 & 0.07 & 0.04 & 0.02 & 0.01 & 0.01 & 0.0 & 0.014 & 4 & & & Con & & 0.02 & \begin{tabular}{ll|}
2 & 0.02 \\
\end{tabular} & 0.03 & $\begin{array}{ll}3 & 0.02 \\
\end{array}$ & 0.03 & $\begin{array}{l}30.09 \\
\end{array}$ \\
\hline \multicolumn{25}{|l|}{ C-Treatmer } \\
\hline Cor & 45.4 & 46.2 & 59.9 & 60.4 & 40.2 & 40.6 & 2.58 & 2.58 & 1.21 & 1.21 & 0.53 & $\begin{array}{ll}3 & 0.53\end{array}$ & 0.91 & 0.887 & 70.534 & 0.527 & 70.251 & 0.250 & 00.5 & $5 \mid 0.55$ & 0.7 & 0.81 & 0.8 & 0.96 \\
\hline $\mathrm{Zr}$ & 3.0 & 53.5 & 99.1 & 99.9 & 98.0 & 98.9 & 3.03 & 2.99 & 2.17 & 2.14 & 1.03 & \begin{tabular}{l|l}
3 & 1.03
\end{tabular} & 0.98 & 0.954 & 40.879 & 0.8 & 50.550 & or & $\begin{array}{ll}7 & 0.7\end{array}$ & 70.79 & \begin{tabular}{l|l}
9 & 1.0
\end{tabular} & 1.10 & 1.8 & 1.83 \\
\hline M & & 49.3 & 92.1 & 92.5 & 79.1 & 79.7 & 3.51 & 3.45 & 2.12 & 2. & 0.86 & 0.86 & 1.11 & 1.074 & 0.00 & & 70.454 & 40. & $\begin{array}{ll}3 & 0.5\end{array}$ & $5 \mid 0.59$ & \begin{tabular}{|l|l|}
9 & 0.8
\end{tabular} & 0.87 & 1.2 & 1.31 \\
\hline $\mathrm{Fe}$ & 47.6 & 48.3 & 88.0 & 89.5 & 77.2 & 77.8 & 3.55 & 3.50 & 2.08 & 2.09 & 0.85 & 50.85 & 1.14 & 1.105 & 50.877 & 77 & 70.452 & 0.450 & 0.5 & $5 \mid 0.56$ & 0.7 & 0.79 & 1.0 & 1.15 \\
\hline $\mathrm{Zn}+\mathrm{mn}$ & 54.2 & 54.3 & 101.8 & 102.4 & +101.4 & 102.1 & 2.7 & 2.73 & 2.11 & 2.12 & 1.11 & \begin{tabular}{l|l}
1 & 1.08
\end{tabular} & 0.94 & 0. & 0.8 & 0.867 & 70.572 & 20.559 & 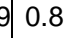 & 30.87 & 71.1 & 1.12 & 1.7 & 1.81 \\
\hline & 52.0 & 52.5 & 99.8 & 100.5 & 100.0 & 100.5 & 2.72 & 2.69 & 2.10 & 2. & 1.05 & $5 \mid 1.06$ & 0.93 & & & & 0 & & \begin{tabular}{ll|l|}
7 & 0.7
\end{tabular} & $\begin{array}{l}7 \\
7\end{array}$ & 1.0 & 1.03 & 1.6 & 1.74 \\
\hline N & 49.9 & 50.5 & 93.7 & 94.6 & 80.4 & 81.1 & 3.54 & 3.52 & 2.20 & 2.19 & 0.86 & 0.87 & 1.08 & 1.050 & o & 36 & 60.452 & 20 & $\begin{array}{lll}3 & 0.6\end{array}$ & 0.62 & 0.7 & 0.83 & 1.1 & 1.21 \\
\hline & 57.7 & 58.2 & 105.4 & 106.2 & 103.2 & 104.0 & 2.93 & 2.91 & 2.14 & 2 & 1.07 & 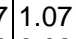 & 0.99 & & & & 9 & 9. & 0.8 & $\begin{array}{lll}3 & 0.93 \\
\end{array}$ & \begin{tabular}{l|l}
3 & 1.1 \\
\end{tabular} & 1.21 & 1.8 & 1.88 \\
\hline Lsd at $5 \%$ & 0.33 & 0.43 & 0.37 & 0.47 & 0.31 & 0.45 & 0.10 & 0.06 & 0.03 & 0.02 & 0.02 & 0.02 & 0.02 & 0.0 & 00 & 00 & .0 & 0.0 & 0.03 & $\begin{array}{ll}3 & 0.02 \\
\end{array}$ & 0.04 & $\begin{array}{l}40.02 \\
\end{array}$ & 0.05 & 50.13 \\
\hline \multicolumn{25}{|l|}{ D-Applicationmethods: } \\
\hline & 53.3 & 53.8 & 94.8 & 95.6 & 86.6 & 87.2 & 2.9 & 2.89 & 1.97 & 1.98 & 0.90 & 0.90 & 0.976 & 60.95 & $\mid 0.817$ & 0.81 & 0.47 & 20.470 & 0.7 & 0.78 & 1.0 & 1.04 & 1.4 & 1.59 \\
\hline $\mathrm{Gr}$ & 48.8 & 49.4 & 90.1 & 90.9 & 83.3 & 74.0 & 3.24 & 3.21 & 2.06 & 2.06 & 0.94 & $\begin{array}{l}40.93 \\
\end{array}$ & 1.039 & $\begin{array}{l}9 \\
9.010 \\
\end{array}$ & 0.854 & 0.844 & 0.490 & 0.486 & \begin{tabular}{l|l|}
6 & 0.6 \\
\end{tabular} & 0.65 & 0.8 & 0.90 & 1.3 & 1.39 \\
\hline E- Interactions: & ** & ** & ** & ** & ** & ** & ** & ** & ** & ** & ** & ** & ** & $\star \star \star$ & ** & ** & ** & ** & $\overline{k \star}$ & ** & ** & ** & ** & \\
\hline A & ** & ** & ** & x* & ** & ** & ** & $\star \star \star$ & ** & ** & ** & ** & ** & $\star \star \star$ & ** & $\star \star$ & ** & ** & ** & ** & ** & ** & ** & ** \\
\hline$A \times C$ & ** & ** & ** & $\star *$ & ** & ** & $* \star \star$ & ** & ** & ** & ** & ** & & t* & ** & ** & ** & & ** & ** & ** & ** & ** & ** \\
\hline B & ** & ** & ** & ** & ** & ** & ** & ** & ** & ** & ** & * & & * & ** & ** & & & 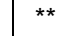 & * & ** & $* *$ & ** & ** \\
\hline$A \times B \times$ & ** & ** & ** & ** & ** & * & ** & ** & NS & NS & NS & ** & ** & ** & NS & ** & ** & ** & ** & ** & * & * & ** & * \\
\hline
\end{tabular}




\begin{tabular}{|c|c|c|c|c|c|c|c|c|c|c|c|c|c|c|c|c|c|c|c|c|c|c|c|c|}
\hline$A \times D$ & ** & ** & ** & * & ** & $* *$ & ** & ** & ** & ** & ** & ** & NS & * & $\star * *$ & NS & ** & ** & NS & NS & * & ** & ** & \\
\hline$B \times D$ & * & ** & ** & * & ** & ** & * & ** & NS & NS & ** & ** & NS & * & NS & $* *$ & NS & * & * & * & * & ** & * & * \\
\hline$A \times B \times D$ & ** & ** & ** & ** & ** & NS & NS & ** & ** & ** & ** & $\star \star \star ~$ & $\star \star *$ & ** & $\star \star *$ & $\star \star *$ & ** & ** & * & ** & ** & ** & * & * \\
\hline$C \times D$ & ** & ** & ** & ** & ** & ** & $*$ & ** & NS & NS & ** & ** & * & ** & ** & $* *$ & ** & ** & * & ** & * & NS & * & ** \\
\hline$A \times C \times D$ & * & ** & ** & ** & ** & $\star \star *$ & NS & ** & ** & ** & ** & 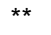 & NS & ** & $\star \star *$ & ** & 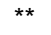 & ** & * & NS & * & * & NS & * \\
\hline $\begin{array}{c}B \times C \times D \\
A \times B \times C \times D\end{array}$ & * & ** & ** & ** & ** & * & NS & ** & ** & ** & $\star \star \star ~$ & * & * & ** & $\star \star \star$ & $* *$ & $\star \star *$ & NS & * & & & * & & \\
\hline
\end{tabular}

Table (5): Leaves fresh weight $(\mathrm{g})$, leaves dry weight $(\mathrm{g})$, stem fresh weight $(\mathrm{g})$ and stem dry weight $(\mathrm{g})$, of corn plant as affected by cultivars, salinity levels, trace-elements treatments and application methods throughout the experimental period at 35 (A1), 65 (A2) and 115 (A3) days from sowing during the two growing seasons of 2002 and 2003.

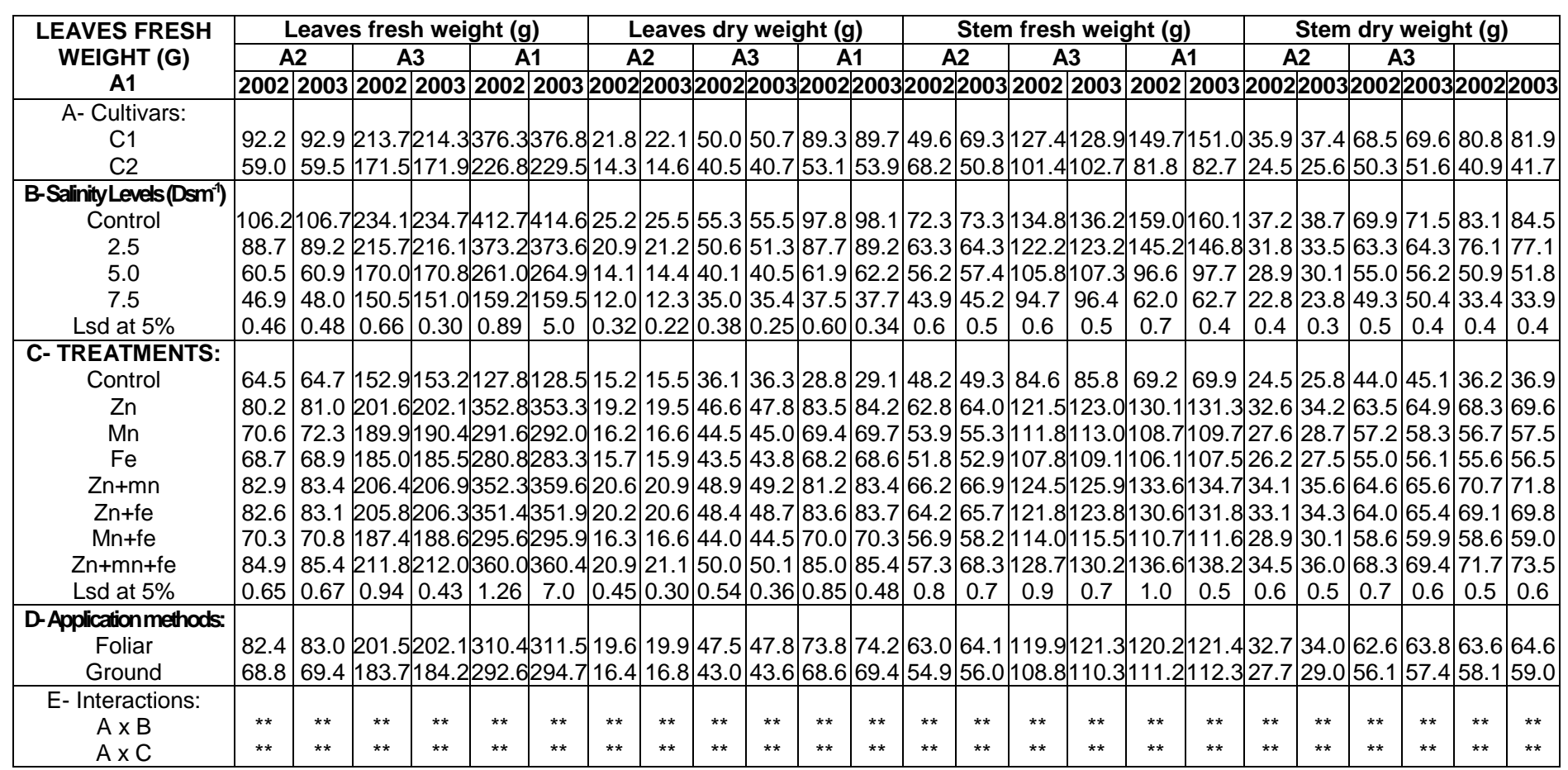


Helaly, M. N. et al.

\begin{tabular}{|c|c|c|c|c|c|c|c|c|c|c|c|c|c|c|c|c|c|c|c|c|c|c|c|c|}
\hline$B \times C$ & $\star * *$ & ** & ** & ** & ** & ** & ** & $* *$ & ** & ** & ** & ** & ** & ** & ** & ** & ** & ** & ** & ** & ** & ** & ** & ** \\
\hline$A \times B \times C$ & ** & ** & $* *$ & ** & ** & ** & ** & ** & ** & $* *$ & ** & ** & ** & ** & ** & * & ** & ** & $\star \star$ & * & ** & * & $\star *$ & ** \\
\hline$A \times D$ & ** & ** & $* *$ & ** & ** & $\star \star *$ & NS & * & ** & NS & ** & ** & NS & * & ** & * & * & NS & NS & NS & $\star *$ & * & $\star *$ & * \\
\hline$B \times D$ & ** & ** & ** & ** & ** & NS & 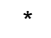 & ** & ** & $* \star$ & ** & ** & $* *$ & ** & * & ** & ** & * & * & $* *$ & * & NS & * & ** \\
\hline$A \times B \times D$ & ** & ** & ** & ** & ** & * & ** & ** & NS & ** & ** & ** & * & ** & ** & ** & ** & ** & ** & $\star *$ & * & $*$ & ** & ** \\
\hline$C \times D$ & ** & ** & ** & ** & ** & * & ** & ** & ** & ** & ** & ** & ** & * & ** & * & ** & ** & * & * & ** & * & ** & * \\
\hline$A \times C \times D$ & ** & ** & ** & ** & ** & NS & * & $\star *$ & ** & ** & ** & ** & ** & ** & ** & ** & ** & ** & ** & ** & $\star \star *$ & ** & * & ** \\
\hline$B \times C \times D$ & ** & ** & ** & ** & ** & * & * & ** & ** & ** & ** & ** & ** & * & * & ** & ** & * & NS & $\star *$ & NS & NS & $* *$ & * \\
\hline$A \times B \times C \times D$ & ** & ** & ** & ** & ** & NS & * & ** & ** & ** & ** & ** & * & ** & ** & * & ** & ** & & $* *$ & $* *$ & & ** & $* *$ \\
\hline
\end{tabular}


Table (6): Root fresh weight (g), root dry weight (g), fresh weight of whole (g) and dry weight of whole (g),of corn plant as affected by cultivars, salinity levels, trace-elements treatments and application methods throughout the experimental period at 35 (A1), 65 (A2) and 115 (A3) days from sowing during the two growing seasons of 2002 and 2003.

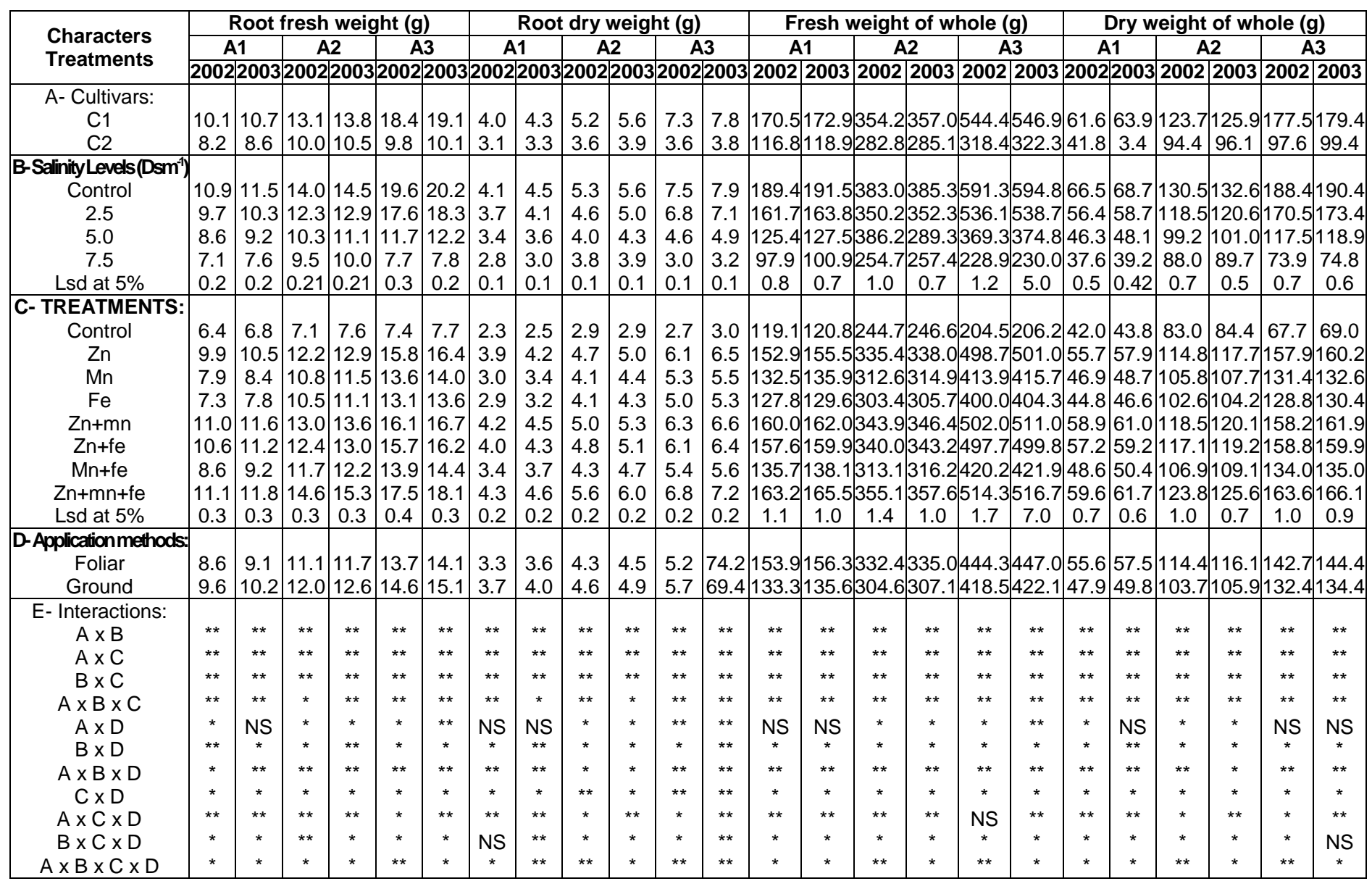


Helaly, M. N. et al.

9042 
Table (7): Specific leaf weight, leaf weight ratio and root/shoot ratio of corn plant as affected by cultivars, salinity levels, trace-elements treatments and application methods throughout the experimental period at 35 (A1), 65 (A2) and 115 (A3) days from sowing during the two growing seasons of 2002 and 2003.

\begin{tabular}{|c|c|c|c|c|c|c|c|c|c|c|c|c|c|c|c|c|c|c|}
\hline \multirow{3}{*}{\begin{tabular}{|l|} 
Characters \\
Treatments \\
\end{tabular}} & \multicolumn{6}{|c|}{ Specific leaf weight (SLW) } & \multicolumn{6}{|c|}{ Leaf weight ratio(LWR) } & \multicolumn{6}{|c|}{ Root/shoot ratio } \\
\hline & \multicolumn{2}{|c|}{ A1 } & \multicolumn{2}{|c|}{$\overline{A 2}$} & \multicolumn{2}{|c|}{$\overline{A 3}$} & \multicolumn{2}{|c|}{ A1 } & \multicolumn{2}{|c|}{ A2 } & \multicolumn{2}{|c|}{ A3 } & \multicolumn{2}{|c|}{ A1 } & \multicolumn{2}{|c|}{ A2 } & \multicolumn{2}{|c|}{ A3 } \\
\hline & 2002 & 2003 & 002 & 2003 & 2002 & 2003 & 2002 & 2003 & 2002 & 2003 & 2002 & 2003 & 2002 & 2003 & 2002 & 2003 & 2002 & 2003 \\
\hline $\begin{array}{c}\text { A- Cultivars: } \\
\text { C1 } \\
\text { C2 }\end{array}$ & $\begin{array}{l}36.59 \\
31.58\end{array}$ & $\begin{array}{l}36.85 \\
31.94\end{array}$ & $\begin{array}{l}48.34 \\
43.07\end{array}$ & $\begin{array}{l}48.65 \\
42.88\end{array}$ & $\begin{array}{l}80.62 \\
47.79\end{array}$ & \begin{tabular}{|l|}
80.47 \\
48.00
\end{tabular} & $\begin{array}{l}0.348 \\
0.322\end{array}$ & $\begin{array}{l}0.341 \\
0.317\end{array}$ & $\begin{array}{l}0.403 \\
0.401\end{array}$ & $\begin{array}{l}0.401 \\
0.396\end{array}$ & \begin{tabular}{|l|}
0.472 \\
0.329
\end{tabular} & $\begin{array}{l}0.469 \\
0.376\end{array}$ & $\begin{array}{l}0.112 \\
0.125\end{array}$ & & $\begin{array}{l}0.077 \\
0.067\end{array}$ & $\begin{array}{l}0.080 \\
0.071\end{array}$ & $\begin{array}{l}0.085 \\
0.055\end{array}$ & $\begin{array}{l}0.089 \\
0.057\end{array}$ \\
\hline \begin{tabular}{|c} 
B-Salinity Levels \\
(Dsm-1) $^{-1}$ \\
Control \\
2.5 \\
5.0 \\
7.5 \\
Lsd at $5 \%$ \\
\end{tabular} & $\begin{array}{c}44.23 \\
38.61 \\
27.95 \\
25.54 \\
0.62 \\
\end{array}$ & \begin{tabular}{c|}
44.53 \\
38.98 \\
28.21 \\
25.86 \\
0.43 \\
\end{tabular} & $\begin{array}{c}53.62 \\
50.87 \\
42.06 \\
36.26 \\
0.38 \\
\end{array}$ & $\begin{array}{c}53.47 \\
51.24 \\
42.03 \\
36.32 \\
0.29 \\
\end{array}$ & $\begin{array}{c}84.94 \\
78.42 \\
56.76 \\
36.70 \\
0.56 \\
\end{array}$ & \begin{tabular}{|c|}
84.52 \\
79.24 \\
56.64 \\
36.54 \\
0.38 \\
\end{tabular} & \begin{tabular}{|l|}
0.380 \\
0.367 \\
0.297 \\
0.296 \\
0.005 \\
\end{tabular} & $\begin{array}{l}0.373 \\
0.358 \\
0.293 \\
0.291 \\
0.003 \\
\end{array}$ & \begin{tabular}{l|l|}
0.425 \\
0.429 \\
0.380 \\
0.375 \\
0.002 \\
\end{tabular} & $\begin{array}{l}0.420 \\
0.428 \\
0.376 \\
0.372 \\
0.002 \\
\end{array}$ & \begin{tabular}{|l|}
0.521 \\
0.495 \\
0.364 \\
0.222 \\
0.002 \\
\end{tabular} & $\begin{array}{l}0.517 \\
0.591 \\
0.361 \\
0.221 \\
0.001\end{array}$ & $\begin{array}{l}0.113 \\
0.121 \\
0.119 \\
0.120 \\
0.003 \\
\end{array}$ & \begin{tabular}{|l|}
0.119 \\
0.125 \\
0.122 \\
0.123 \\
0.002 \\
\end{tabular} & $\begin{array}{l}0.075 \\
0.073 \\
0.069 \\
0.072 \\
0.001 \\
\end{array}$ & $\begin{array}{l}0.078 \\
0.078 \\
0.072 \\
0.073 \\
0.001 \\
\end{array}$ & $\begin{array}{l}0.090 \\
0.088 \\
0.063 \\
0.039 \\
0.001 \\
\end{array}$ & $\begin{array}{l}0.093 \\
0.092 \\
0.066 \\
0.041 \\
0.001\end{array}$ \\
\hline \begin{tabular}{|c} 
C-Treatments: \\
Control \\
$\mathrm{Zn}$ \\
$\mathrm{Mn}$ \\
$\mathrm{Fe}$ \\
$\mathrm{Zn}+\mathrm{mn}$ \\
$\mathrm{Zn}+\mathrm{fe}$ \\
$\mathrm{Mn}+\mathrm{fe}$ \\
$\mathrm{Zn}+\mathrm{mn}+\mathrm{fe}$ \\
Lsd at $5 \%$ \\
\end{tabular} & $\begin{array}{c}31.19 \\
35.18 \\
32.14 \\
31.69 \\
37.22 \\
38.09 \\
31.64 \\
35.52 \\
0.87 \\
\end{array}$ & $\begin{array}{c}31.32 \\
35.48 \\
32.47 \\
31.84 \\
37.99 \\
38.55 \\
31.87 \\
35.63 \\
0.61 \\
\end{array}$ & $\begin{array}{c}32.43 \\
46.76 \\
47.87 \\
48.97 \\
47.78 \\
48.18 \\
46.45 \\
47.18 \\
0.53 \\
\end{array}$ & $\begin{array}{c}32.37 \\
47.52 \\
48.24 \\
48.49 \\
47.73 \\
48.20 \\
46.58 \\
46.99 \\
0.41 \\
\end{array}$ & $\begin{array}{c}26.87 \\
74.48 \\
65.74 \\
66.24 \\
69.92 \\
73.06 \\
65.29 \\
72.04 \\
0.79 \\
\end{array}$ & \begin{tabular}{|c}
26.90 \\
74.38 \\
65.46 \\
66.09 \\
71.39 \\
72.86 \\
64.97 \\
71.82 \\
0.54 \\
\end{tabular} & $\begin{array}{l}0.313 \\
0.335 \\
0.336 \\
0.340 \\
0.343 \\
0.347 \\
0.324 \\
0.344 \\
0.007 \\
\end{array}$ & $\begin{array}{l}0.306 \\
0.328 \\
0.331 \\
0.333 \\
0.337 \\
0.342 \\
0.318 \\
0.337 \\
0.005\end{array}$ & $\begin{array}{l}0.327 \\
0.406 \\
0.420 \\
0.423 \\
0.414 \\
0.414 \\
0.410 \\
0.404 \\
0.004 \\
\end{array}$ & $\begin{array}{l}0.323 \\
0.406 \\
0.417 \\
0.420 \\
0.410 \\
0.409 \\
0.407 \\
0.400 \\
0.003 \\
\end{array}$ & \begin{tabular}{|l|}
0.180 \\
0.465 \\
0.398 \\
0.398 \\
0.451 \\
0.463 \\
0.393 \\
0.457 \\
0.003 \\
\end{tabular} & $\begin{array}{l}0.178 \\
0.490 \\
0.422 \\
0.423 \\
0.481 \\
0.487 \\
0.419 \\
0.481 \\
0.002\end{array}$ & $\begin{array}{l}0.084 \\
0.121 \\
0.120 \\
0.120 \\
0.126 \\
0.123 \\
0.124 \\
0.127 \\
0.004 \\
\end{array}$ & $\begin{array}{l}0.088 \\
0.125 \\
0.126 \\
0.124 \\
0.130 \\
0.128 \\
0.129 \\
0.129 \\
0.003 \\
\end{array}$ & $\begin{array}{l}0.049 \\
0.074 \\
0.072 \\
0.074 \\
0.078 \\
0.074 \\
0.074 \\
0.082 \\
0.002 \\
\end{array}$ & $\begin{array}{l}0.049 \\
0.077 \\
0.076 \\
0.077 \\
0.082 \\
0.078 \\
0.078 \\
0.086 \\
0.002 \\
\end{array}$ & $\begin{array}{l}0.037 \\
0.079 \\
0.070 \\
0.067 \\
0.078 \\
0.078 \\
0.069 \\
0.084 \\
0.002\end{array}$ & $\begin{array}{l}0.039 \\
0.082 \\
0.072 \\
0.070 \\
0.081 \\
0.081 \\
0.072 \\
0.086 \\
0.002\end{array}$ \\
\hline $\begin{array}{c}\text { D-Application } \\
\text { methods: } \\
\text { Foliar } \\
\text { Ground }\end{array}$ & $\begin{array}{l}35.76 \\
32.43\end{array}$ & $\begin{array}{c}36.08 \\
32.7\end{array}$ & $\begin{array}{l}46.80 \\
44.61\end{array}$ & $\begin{array}{l}46.75 \\
44.79 \\
\end{array}$ & $\begin{array}{l}65.29 \\
63.12\end{array}$ & $\begin{array}{l}65.20 \\
63.11\end{array}$ & $\begin{array}{l}0.341 \\
0.329 \\
\end{array}$ & $\begin{array}{l}0.335 \\
0.322 \\
\end{array}$ & $\begin{array}{l}0.402 \\
0.402\end{array}$ & $\begin{array}{l}0.399 \\
0.399\end{array}$ & $\begin{array}{l}0.401 \\
0.400\end{array}$ & $\begin{array}{l}0.422 \\
0.422 \\
\end{array}$ & $\begin{array}{l}0.102 \\
0.134 \\
\end{array}$ & $\begin{array}{l}0.106 \\
0.139 \\
\end{array}$ & $\begin{array}{l}0.066 \\
0.078 \\
\end{array}$ & $\begin{array}{l}0.068 \\
0.083\end{array}$ & $\begin{array}{l}0.064 \\
0.076\end{array}$ & $\begin{array}{l}0.067 \\
0.079 \\
\end{array}$ \\
\hline $\begin{array}{c}\text { E- } \\
\text { Interactions: } \\
A \times B \\
A \times C \\
B \times C \\
A \times B \times C \\
A \times D \\
B \times D \\
A \times B \times D \\
C \times D \\
A \times C \times D \\
B \times C \times D\end{array}$ & $\begin{array}{c}* * \\
* * \\
* * \\
* * \\
* * \\
N S \\
* * \\
* * \\
* \\
* \\
*\end{array}$ & $\begin{array}{l}* * \\
* * \\
* * \\
* * \\
* * \\
* \\
* * \\
* * \\
* * \\
* * \\
* *\end{array}$ & $\begin{array}{l}* * \\
* * \\
* * \\
* * \\
* * \\
* * \\
N S \\
* * \\
* \\
* * \\
* * \\
*\end{array}$ & $\begin{array}{l}* * \\
* * \\
* * \\
* * \\
N S \\
* * \\
* \\
* * \\
N S \\
* * \\
* *\end{array}$ & $\begin{array}{c}* * \\
* * \\
* * \\
* * \\
N S \\
* * \\
* \\
* * \\
* * \\
* * \\
* * \\
\end{array}$ & $\begin{array}{c}* * \\
* * \\
* * \\
* * \\
* * \\
* * \\
* \\
* * \\
* \\
* \\
\text { NS }\end{array}$ & $\begin{array}{c}* * \\
* * \\
* * \\
* * \\
* \\
* * \\
* * \\
N S \\
* \\
* \\
\text { NS }\end{array}$ & $\begin{array}{l}* * \\
* * \\
* * \\
* * \\
* * \\
* * \\
* * \\
* * \\
* * \\
* * \\
* *\end{array}$ & $\begin{array}{c}* * \\
* * \\
* * \\
* * \\
N S \\
* \\
* \\
* * \\
* * \\
* * \\
* *\end{array}$ & $\begin{array}{c}* * \\
* * \\
* * \\
* * \\
N S \\
* \\
* * \\
* * \\
N S \\
* * \\
* * \\
* * \\
\end{array}$ & $\begin{array}{l}* * \\
* * \\
* * \\
* * \\
* * \\
* * \\
* * \\
* * \\
* * \\
* * \\
* *\end{array}$ & $\begin{array}{c}* * \\
* * \\
* * \\
* * \\
* * \\
* * \\
* * \\
* \\
\mathrm{NS} \\
* \\
\mathrm{NS}\end{array}$ & $\begin{array}{c}* * \\
* * \\
* * \\
* * \\
* \\
* \\
* \\
* \\
* \\
* \\
* \\
\text { NS }\end{array}$ & $\begin{array}{l}* * \\
* * \\
* * \\
* * \\
N S \\
* \\
* \\
* * \\
* \\
* \\
*\end{array}$ & $\begin{array}{c}* * \\
* * \\
* * \\
* * \\
N S \\
* \\
* * \\
* * \\
* * \\
* * \\
* * \\
*\end{array}$ & $\begin{array}{l}* * \\
* * \\
* * \\
* * \\
* \\
* \\
N S \\
\text { N* } \\
* * \\
* \\
*\end{array}$ & $\begin{array}{l}* * \\
* * \\
* * \\
* * \\
* * \\
* * \\
* * \\
* * \\
* * \\
* * \\
* * \\
* * \\
* *\end{array}$ & 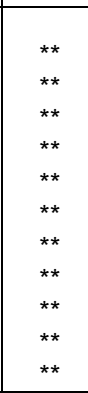 \\
\hline
\end{tabular}


Helaly, M. N. et al.

\begin{tabular}{|l|l|l|l|l|l|l|l|l|l|l|l|l|l|l|l|l|}
\hline $\mathrm{A} \times \mathrm{B} \times \mathrm{C} \times \mathrm{D}$ & & & & & & & & & & & & & & & & \\
\hline
\end{tabular} 